\title{
IMPACT OF INORGANIC FERTILIZATION ON SORGHUM FORAGE QUALITY AND GROWTH PERFORMANCE OF BARKI LAMBS
}

\author{
K. Z. Kewan*1, I.M. Khattab ${ }^{2}$, A.M. Abdelwahed ${ }^{1}$, U.A. Nayel ${ }^{3}$ \\ ${ }^{1}$ Department of Animal and Poultry Nutrition, Desert Research Center, El-Mataria, Cairo, Egypt. \\ ${ }^{2}$ Department of Animal and Fish Production, Faculty of Desert and Environmental Agriculture, \\ Matrouh University, Matrouh, Egypt. \\ ${ }^{3}$ Department of Animal Production, Faculty of Agriculture, Menoufia University, Shibin El-Kom, \\ Menoufia, Egypt.
}

*Corresponding author: kewandrc@yahoo.com

(Received 28/2/2021, accepted 27/3/2021)

\section{SUMMARY}

$\mathrm{T}$ The present study was conducted at Maryout Research Station, Desert Research Center. It was applied in two experiments (Agronomy and fodder evaluation experiment and animal growth experiment) to determine the response of sorghum quality and consequently the animal performance to the application of combined $\mathrm{N}$ and $\mathrm{P}$ fertilizer in newly reclaimed soil. The first experiment was for evaluating sorghum fodder (Sorghum bicolor $L$.) that sorted with nine treatment combinations (from T1 up to T9) comprising of three nitrogen (N) and phosphorus (P) fertilizers levels $\left(\mathrm{N}_{80.4}, \mathrm{~N}_{100.5}\right.$ and $\mathrm{N}_{120.6}$ $\mathrm{kg} /$ feddan vs. $\mathrm{P}_{20.2}, \mathrm{P}_{30.2}$ and $\mathrm{P}_{40.3} \mathrm{~kg} /$ feddan) in factorial randomized block design with three replications. The results of the agronomy experiment with considering the ISDMD, NEg and the cost of treatments, showed that two treatments $\left(\mathrm{N}_{120} \mathrm{P}_{30}\right.$ and $\left.\mathrm{N}_{100} \mathrm{P}_{40}\right)$ could be nominated to the second experiment which was their evaluation as feeds for the growing Barki lambs as compared to control treatment $\left(\mathrm{N}_{80} \mathrm{P}_{20}\right)$. So, two treatments and control were sorting again in the next summer season to evaluate their nutritive values by using 15 growing Barki lambs (5 lambs/ treatment) in a completely randomized block design. Lambs were on average $22.83 \pm 0.29 \mathrm{~kg}$ as the initial body weight and aged 5 months. All animals fed concentrate feed mixture to cover $70 \%$ of their growth requirements (Kearl, 1982). However, the experimental fodders were offered ad lib. So the experimental animal groups were allowed for three rations for $85 \mathrm{~d}$ as follows; $\mathrm{R} 1$ : CFM + sorghum forage of $\mathrm{T} 1\left(\mathrm{~N}_{80} \mathrm{P}_{20}\right)$ ad lib., (served as a control), R2: CFM + sorghum forage of $\mathrm{T} 6\left(\mathrm{~N}_{120} \mathrm{P}_{30}\right)$ ad lib, and R3: CFM + sorghum forage of T8 $\left(\mathrm{N}_{100} \mathrm{P}_{40}\right)$ ad lib. The results indicated that; Average daily gain differed significantly $(\mathrm{P}=0.016)$ being values 158 , 185 and 192g for lambs fed R1, R2 and R3, respectively. Animals in R2 and R3 consumed a higher ( $\mathrm{P}=0.042)$ amount of sorghum compared with the control one. There is a significant effect $(\mathrm{P}<0.05)$ of sorghum treatments on feed conversion ratio (FCR), where sheep fed R1 or R2 had better FCR as $\mathrm{g}$ DM/ $g$ gain or $\mathrm{g}$ TDN/ $\mathrm{g}$ gain than those fed control sorghum ration. However, R1 revealed better FCR as $\mathrm{g}$ DCP/g gain as compared with the other groups. The digestibilities of DM, CP and CF were higher $(\mathrm{P}<0.05)$ for $\mathrm{R} 2$ and $\mathrm{R} 3$ compared to the control one. However, digestibilities of EE and NFE were not affected $(\mathrm{P}>0.05)$ by the experimental rations. Both R2 and R3 were the better $(\mathrm{P}<0.05)$ for both TDN and DCP values as compared with the control ration. Higher $(\mathrm{P}<0.05) \mathrm{N}$ balance was observed with R2 than control. All lambs retained relatively similar $(\mathrm{P}>0.05)$ amounts of calcium. However, higher $\mathrm{P}$ content in sorghum of $\mathrm{R} 2$ and $\mathrm{R} 3$ revealed significantly higher $\mathrm{P}$ intake $(\mathrm{P}<0.05)$ and also $\mathrm{P}$ retained $(\mathrm{P}<0.05)$. The revealed insensible water loss $(\mathrm{IWL})$ of the three groups was significantly different being values 144,172 and $176 \mathrm{~g} / \mathrm{kg}^{0.82}$ for $\mathrm{R} 1, \mathrm{R} 2$ and $\mathrm{R} 3$, respectively. The rumen $\mathrm{pH}$ value of animal group fed control ration $(\mathrm{R} 1)$ was significantly $(\mathrm{P} \leq 0.001)$ higher than other groups at all the sampling time. Animals who received $\mathrm{R} 2$ ration showed the highest $\mathrm{NH}_{3}-\mathrm{N}$ values at $3 \mathrm{~h}(\mathrm{P}<0.01)$ and $6 \mathrm{~h}(\mathrm{P}<0.05)$ post-feeding as compared to the other groups; however $\mathrm{R} 3$ group showed the highest $(\mathrm{P}<0.05)$ value at zero hour post-feeding as compared to the groups. At $6 \mathrm{~h}$ post-feeding, animals fed R2 showed the highest $(\mathrm{P}<0.05)$ TVFA value $(22.14 \mathrm{meq} / \mathrm{dl})$ as compared to the other groups (19.68 and $21.45 \mathrm{meq} / \mathrm{dl}$ for R1 and R3, respectively).

It could be concluded that both of the sorghum treatments; $\mathrm{N}_{120} \mathrm{P}_{30}$ and $\mathrm{N}_{100} \mathrm{P}_{40} \mathrm{~kg} / \mathrm{fed}$; are in the same nutritive values and similar growth rate for Barki lambs but because of higher $\mathrm{P}$ drain away to the land below in case of $\mathrm{N}_{100} \mathrm{P}_{40}$ ration so it is recommended for $\mathrm{N}_{120} \mathrm{P}_{30}$ to be a better fertilizer rate for the fodder consumed by the Barki 


\section{Kewan et al.}

lambs and also for its potential to reduce the environmental pollution with the high level of $\mathrm{P}$ compared to the other treatment.

Keywords: Sorghum, fertilizer, gas production, lamb, growth, fermentation and blood parameters.

\section{INTRODUCTION}

The livestock production industry in Egypt relies on the availability and quality of green fodders as feed for ruminants, which is strongly associated with the variety of plant and fertilizer applications during the lifetime of the plant. Nitrogen expressed as digestible crude protein (DCP \%) is one of the main indicators of fodder quality. Meanwhile, phosphorus is extremely important in ruminant metabolic processes as it is involved in the formation of energetic compounds (AMP, ADP and ATP), the growth of living cells and the synthesis of microbial proteins which contributes about $40-80 \%$ of the amino acids absorbed in the intestine (Karsil and Russell, 2001). Phosphorus is also considered an important mineral element in plant nutrition, especially in calcareous soils that are always poor in this element because of the high calcium carbonate content and alkalinity of the soil (Korkmaz et al., 2009). The calcareous lands account for a large part of the reclaimed land in Egypt (Khattari and Tell, 1988).

The most important constraint for ruminant production in the tropic and sub-tropic areas is a shortage of feed in terms of quality, especially in the dry season. When ruminants fed low-quality roughage, this result in low milk and beef production as well as caused deterioration of animal health (Chakravarthi et al., 2017). The forage Sorghum bicolor $L$. is a common perennial plant and is often grown in areas of relatively low rainfall, high temperatures and with saline soils (Sanchez et al., 2002). Sorghum ranks fifth among the world's most important crops (Getachew et al., 2016). Chakravarthi et al. (2017) stated that sorghum is considered one of the forage crops that withstand drought compared to corn. Besides, the main advantages of sorghum are its uses in feeding ruminants in different forms, whether in the green state, hay, or silage, as well as grains, which are almost similar to corn grains in their nutritional value. However, there is a voracious need for nitrogen fertilization, which in turn is the cause of an increase in crop yield from nitrates and prussic acid (Astuti et al., 2019), and these compounds are considered to be toxic to ruminants at a certain level and are formed as a result of an imbalance between nitrogen and phosphorus or a decrease in the phosphorus content of the soil, as is the case for calcareous soils. The safe limit of hydrocyanic acid (HCN) in green forage for livestock is $500 \mathrm{ppm}$ on a fresh weight basis (Karthika and Kalpana, 2017). Thiex (2002) found that increased phosphorus resulted in a lower concentration of prussic acid and nitrates in the plant, making its diet safe for ruminants. Singh et al. (2008) indicated that the major factors limiting sorghum fodder production are related to specific growth stages, insufficient fertilizer application, and high contents of HCN. To achieve a higher yield and quality of crops, it is essential to provide them the optimum level of their nutrients requirements as fertilizers. Therefore, the present study was conducted to determine the response of sorghum quality and consequently the animal performance to the application of combined $\mathrm{N}$ and $\mathrm{P}$ fertilizers in newly reclaimed soil.

\section{MATERIALS AND METHODS}

This study was carried out at Maryout Research Station, Desert Research Center (DRC), Egypt, and it was applied in two experiments in two consecutive summer seasons. A part of the chemical analysis was progressed in the Lab of Animal Production, Department of Animal Production, Faculty of Agriculture, Menoufia University.

\section{Agronomy experiment and fodder evaluation:}

The forage sorghum (Sorghum bicolor L.) was cultivated during the summer season in reclaimed calcareous soil. The flood irrigation system was followed throughout the lifetime (130d) of the experimental crops. The experiment was laid out with nine treatment combinations (from T1 up to T9) comprising of three nitrogen $(\mathrm{N})$ and Phosphorus $(\mathrm{P})$ fertilizers levels $\left(\mathrm{N}_{80.4}, \mathrm{~N}_{100.5}\right.$ and $\mathrm{N}_{120.6} \mathrm{~kg} / \mathrm{feddan}$ vs. $\mathrm{P}_{20.2}, \mathrm{P}_{30.2}$ and $\mathrm{P}_{40.3} \mathrm{~kg} /$ feddan) in factorial randomized block design with three replications using forage Sorghum bicolor L. as a test crop. Ammonium nitrate $(33.5 \% \mathrm{~N})$ and superphosphate $(15.5 \%$ $\mathrm{P}_{2} \mathrm{O}_{5}$ ) fertilizers were used as sources for $\mathrm{N}$ and $\mathrm{P}$, respectively. Rates of nitrogenous and phosphorous 
fertilizers and their contribution for $\mathrm{N}$ and $\mathrm{P}$, respectively for sorghum forage as well as their costs are shown in Table (1).

Table (1): Rate of fertilizers for sorghum fodder sorted in calcareous soil.

\begin{tabular}{|c|c|c|c|c|c|c|c|c|c|}
\hline \multirow[t]{2}{*}{ Item } & \multicolumn{9}{|c|}{ 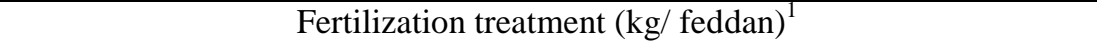 } \\
\hline & $\mathrm{T} 1$ & $\mathrm{~T} 2$ & $\mathrm{~T} 3$ & $\mathrm{~T} 4$ & T5 & T6 & $\mathrm{T} 7$ & T8 & T9 \\
\hline AN fertilizer & 240 & 300 & 360 & 240 & 300 & 360 & 240 & 300 & 360 \\
\hline N element & 80.4 & 100.5 & 120.6 & 80.4 & 100.5 & 120.6 & 80.4 & 100.5 & 120.6 \\
\hline SP fertilizer & 130 & 130 & 130 & 195 & 195 & 195 & 260 & 260 & 260 \\
\hline P element & 20.2 & 20.2 & 20.2 & 30.2 & 30.2 & 30.3 & 40.3 & 40.3 & 40.3 \\
\hline Cost (LE/ Tr./feddan) & 1960 & 2320 & 2680 & 2220 & 2580 & 2940 & 2480 & 2840 & 3200 \\
\hline
\end{tabular}

\section{Fodder yield:}

Fresh fodder yield in three cuttings was recorded and subsamples were dried at $70{ }^{\circ} \mathrm{C}$ to determine the dry weight yield as ton/feddan.

\section{Fodder composition:}

Random plant samples from each plot were taken before harvest for analysis to p-hydroxybenzaldehyde (p.HB) which converted to hydrocyanic acid $(\mathrm{HCN})$ values in ppm as described by Gorz et al. (1977). Dry sorghum samples were analyzed for crude protein (CP), crude fiber (CF), ether extract (EE) and ash according to AOAC (2000). Nitrate content was determined according to Makkar et al. (2007). Calcium and total phosphorus were determined according to VDLUFA (2007) using an Inductively Coupled Argon Plasma Spectrometer, iCAP6500Duo, Thermo Scientific, England, by the Central Lab in the DRC.

\section{Fodder evaluation trials:}

In situ dry matter degradability (ISDMD): In situ bag technique allows intimate contact of the test feed with the rumen environment. Nylon bags $(17 \mathrm{~cm} \times 10 \mathrm{~cm}$ and $45 \mu \mathrm{m}$ of pore size $)$ were filled with a $3 \mathrm{~g}$ dry sorghum sample $(1.0-\mathrm{mm})$ and incubated in the rumen for $72 \mathrm{~h}$. A total of $51 \mathrm{bags}$ were incubated in three ruminally- cannulated Barki rams (3bags $\times 3$ cuts $\times 9$ treatments). All bags were placed in the rumen just before the animals were offered their first meal of the morning. After removal from the rumen, the bags were washed with tap water for 15 min until the washing water was clear. The same procedure was used for two series of two bags to obtain the $0 \mathrm{~h}$ value. Bags were dried at $65^{\circ} \mathrm{C}$ for $48 \mathrm{~h}$ and analyzed for DM. The ISDMD was calculated as the loss in DM, represented as the difference between the incubated DM and residual DM, corrected by blanks.

In vitro gas production: Each forage treatment was evaluated for gas production (GP) (Menke and Steingass, 1988) as a composed dry sample formulated from the three cuts, so a total of nine samples was assessed. An exact of $200 \mathrm{mg}$ of each finely ground sorghum feed was placed into $100 \mathrm{ml}$ glass bottles containing $20 \mathrm{ml}$ of a medium ( $\mathrm{pH} 6.8$ ) containing rumen liquor (10ml) that had been filtered through 4 layers of cheesecloth. The rumen liquor was collected from the ruminally- cannulated rams one hour before the morning feeding. Five bottles were set up for each sorghum treatment. The gas volume was recorded after $24 \mathrm{~h}$ of incubation and the values were corrected for the blank value and GP values are expressed in $\mathrm{ml}$ per $200 \mathrm{mg}$ DM. After recording the final gas volume at $24 \mathrm{~h}$ of incubation, $4 \mathrm{ml} \mathrm{NaOH}$ (10 M) was injected in each bottle to measure methane volume as described by Demeyer et al. (1988).

The feeding values for green fodders (metabolizable energy, ME; digestible organic matter, DOM and net energy for growth, NEg) were calculated by using the amount of gas produced (GP; $\mathrm{ml} / 200 \mathrm{mg} \mathrm{DM}$ ) at $24 \mathrm{~h}$ of incubation with supplementary analysis of CP (g/kg DM), ash $(\mathrm{g} / \mathrm{kg} \mathrm{DM})$ and EE $(\mathrm{g} / \mathrm{kg} \mathrm{DM})$ as follows: 
$\mathrm{ME}(\mathrm{MJ} / \mathrm{kg} \mathrm{DM})=2.20+0.1357 \times \mathrm{GP}+0.0057 \times \mathrm{CP}+0.0002859 \times \mathrm{EE}^{2}($ Getachew et al., 2002).

$\operatorname{DOM}(\% \mathrm{DM})=9.00+0.9991 \mathrm{GP}+0.0595 \mathrm{CP}+0.0181 \mathrm{Ash}($ Getachew et al., 2002).

$\mathrm{NEg}(\mathrm{MJ} / \mathrm{kg} \mathrm{DM})=0.58 \mathrm{ME}-0.52(\mathrm{NRC} 1985)$.

Microbial protein (MCP) was calculated as $19.3 \mathrm{~g}$ microbial N/kg DOM according to Czerkawski (1985).

\section{Animal growth experiment, samples and analysis:}

By investigating the data of the agronomy experiment with considering the ISDMD, NEg and the cost of treatments, two treatments (T6 \& T8) could be nominated to the next evaluation as feeds for the growing lambs as compared to control treatment (T1). So that T6 and T8 vs. T1 were sorting again in the next summer season to evaluate their nutritive values by using 15 growing Barki lambs (5 lambs/ treatment) arranged in a completely randomized block design. Lambs were on average $22.83 \pm 0.29 \mathrm{~kg}$ as the initial body weight and aged 5 months. All animals fed concentrate feed mixture to cover $70 \%$ of their growth requirement as recommended by Kearl (1982). However, the experimental fodders were offered ad lib. So the experimental animal groups were allowed for three rations as follows:

$\mathrm{R} 1: \mathrm{CFM}+$ sorghum forage of $\mathrm{T} 1\left(\mathrm{~N}_{80} \mathrm{P}_{20}\right)$ ad lib. (Served as a control).

$\mathrm{R} 2: \mathrm{CFM}+$ sorghum forage of $\mathrm{T} 6\left(\mathrm{~N}_{120} \mathrm{P}_{30}\right)$ ad lib.

R3: CFM + sorghum forage of $\mathrm{T} 8\left(\mathrm{~N}_{100} \mathrm{P}_{40}\right)$ ad lib.

Lambs were housed individually in shaded pens $(1.5 \times 1.7 \mathrm{~m})$. Along with $85 \mathrm{~d}$, the sorghum was chopped before feeding to generate pieces of $1-5 \mathrm{~cm}$ size to reduce feed selectivity by animals and also maximize feed intake. Animals were fed twice a day (at 09:00 and 15:00 h) and they had free access to fresh water. Lambs were weighed biweekly before the morning feeding throughout the experimental feeding period $(85 \mathrm{~d})$.

At the end of the feeding trial, 12 animals (4 lambs/ diet) were randomly selected and kept in individual metabolic cages for conducting a digestibility trial. It prolonged for 10d of adaptation and a subsequent $5 \mathrm{~d}$ collection period for feces and urine then followed $2 \mathrm{~d}$ for sampling rumen liquor and blood serum. Composite samples of different forages and feces were dried at $60^{\circ} \mathrm{C}$ for $48 \mathrm{~h}$ then milling to pass through a $1 \mathrm{~mm}$ screen and stored for later chemical analysis. The chemical composition of representative samples; CFM, sorghum forages, refusals and feces was determined according to AOAC (2000) procedures.

At the end of the metabolism trial, rumen fluid samples were collected through a stomach tube from each animal at zero time (before feeding), $3 \mathrm{~h}$ and $6 \mathrm{~h}$ post-feeding. These samples were filtered through four layers of surgical gauze without squeezing. Ruminal $\mathrm{pH}$ was immediately recorded by a digital $\mathrm{pH}$ meter. Rumen ammonia-N was determined according to Preston (1995) and total volatile fatty acids (TVFAs) was determined by a Kjeldahl distillation method according to AOAC (1997).

Blood samples were collected from the jugular vein of each lamb of the digestibility trial. Blood was collected into clean test tubes without anticoagulant and centrifuged at $3000 \mathrm{rpm}$ for 20 minutes to obtain serum that was frozen at $-20^{\circ} \mathrm{C}$ for later analysis. Serum concentrations of total protein (TP), albumin (Alb), creatinine $(\mathrm{Cr})$, ammonia $\left(\mathrm{NH}_{3}\right)$, sodium $(\mathrm{Na})$, potassium $(\mathrm{K})$, calcium $(\mathrm{Ca})$ and phosphorus $(\mathrm{P})$ were estimated Calorimetrically following protocols of commercial chemical reagent kits (Bio-diagnostic product Kit, Egypt).

\section{Statistical analysis:}

The data of sorghum production, leaf to stem ratio, chemical composition of sorghum crops, and also $\mathrm{Ca}$ and $\mathrm{P}$ contents were statistically analyzed by two-way analysis of variance using the General Linear Model Procedure of the SAS software (SAS 2002). The model used is: Yijk $=\mu+\mathrm{Ti}+\mathrm{Cj}+(\mathrm{TC}) \mathrm{ij}+\mathrm{eijk}$ where: Yijk= individual observation; $\mu=$ the overall mean; $\mathrm{Ti}=$ the fixed effect of fertilizer treatments; $\mathrm{Cj}=$ the fixed effect of cut number; (TC)ij= the interaction between the treatment and the cut number and eijk = random error. But all the other data were statistically performed as a one-way factor and the mathematical model was as follows: Yij $=\mu+\mathrm{Ti}+$ eij. Where: Yij $=$ Individual observation, $\mu=$ the overall mean for the trial under consideration, $\mathrm{Ti}=$ the effect of the treatment and eij=Random residual error. Mean comparisons were done using Tukey's Honestly Significant Difference (HSD) test (Abdi and Williams, 2010). 


\section{RESULTS AND DISCUSSION}

\section{Sorghum fodder yield:}

Fertilizer application is one of the principles factors that markedly increase the fodder yield. The results in Table (2) showed that the green fodder yields were significantly increased $(\mathrm{p}<0.001)$ with increasing the NP levels but inversely related with the number of the cuts. Maximum fresh fodder yield (ton/ feddan) was observed for T3, T5, T6, T8 and T9. This may be due to the positive effect of $\mathrm{N}$ and $\mathrm{P}$ elements on the availability of soil nutrients and consequently the production of fodder crops. Similar results were obtained by Rashid and Iqbal (2011) and Talpada et al. (2016) on fodder sorghum. Also, Meena et al. (2012) indicated that increasing the level of $\mathrm{N}$ from 40 to $120 \mathrm{~kg} \mathrm{ha}^{-1}$ has recorded a significant increase in green fodder yield of hybrid sorghum. Hussein and Sabbour (2014) reported that increasing $\mathrm{N}$ fertilization up to 60 or $80 \mathrm{~kg}$ N/feddan caused pronounced increases in fresh matter yield and dry matter yield of the $1^{\text {st }}$ and $2^{\text {nd }}$ cuts. These results are in accordance with those of Das et al. (1996) who concluded that DM yield of sorghum increased with increasing the application of $\mathrm{P}$ at all the stages of crop growth. Green fodder yield has increased significantly (11.25-29.5 ton/ha) by increasing fertilizer $\mathrm{N}, \mathrm{P}_{2} \mathrm{O}_{5}$ and $\mathrm{K}_{2} \mathrm{O}$ levels compared to control (Udayakumar and Santhi, 2017). Pooled result of Talpada et al. (2016) showed that 9.6 and $26.9 \%$ higher dry fodder yield was recorded due to level 100:50 NP kg/ ha in comparison to 80:40 NP kg/ha and 60:30 NP kg/ha, respectively.

It seems that the leaf to stem ratio was significantly influenced by fertilizer treatments, cut number and also the interaction between both factors (Table 2). The T8, T4 and T6 showed a higher $(\mathrm{P}<0.05)$ leaf to stem ratio as compared to the control treatment (T1). Al Khalasi et al. (2010) reported that stems represent $70 \%$, leaf sheaths $15.5 \%$, leaves $12.5 \%$ and $1.5 \%$ ears. Mostafa et al. (2010) reported that fodder yield for different sorghum genotypes ranged from 12.4-23.7 ton/feddan however, leaf to stem ratio ranged from 0.13 to 0.35 .

Table (2): Sorghum forage production and the leaf to stem ratio.

\begin{tabular}{|c|c|c|c|c|c|c|c|c|}
\hline \multirow[t]{2}{*}{ Treatment } & \multicolumn{3}{|c|}{$\begin{array}{l}\text { Fresh forage } \\
\text { (ton/fed) }\end{array}$} & \multirow[t]{2}{*}{ Total } & \multicolumn{3}{|c|}{$\begin{array}{c}\text { Leaf: Stem ratio } \\
(\% \text { on } \mathrm{DM})\end{array}$} & \multirow[t]{2}{*}{ Mean } \\
\hline & $1^{\text {st }}$ cut & $2^{\text {nd }}$ cut & $3^{\text {rd }}$ cut & & $1^{\text {st }}$ cut & $2^{\text {nd }}$ cut & $3^{\text {rd }}$ cut & \\
\hline T1 & 14.35 & 12.15 & 6.61 & 33.11 & 2.14 & 1.57 & 0.63 & 1.45 \\
\hline $\mathrm{T} 2$ & 15.32 & 13.18 & 7.04 & 35.54 & 2.17 & 1.48 & 0.80 & 1.48 \\
\hline $\mathrm{T} 3$ & 16.12 & 14.09 & 7.43 & 37.64 & 2.00 & 1.07 & 0.83 & 1.30 \\
\hline $\mathrm{T} 4$ & 14.56 & 12.42 & 7.30 & 34.28 & 2.15 & 2.29 & 0.90 & 1.78 \\
\hline T5 & 15.98 & 13.88 & 7.60 & 37.46 & 1.82 & 1.66 & 0.88 & 1.45 \\
\hline T6 & 16.52 & 14.40 & 8.33 & 39.25 & 1.81 & 1.81 & 1.09 & 1.57 \\
\hline $\mathrm{T} 7$ & 14.76 & 12.63 & 7.01 & 34.40 & 1.74 & 1.71 & 0.72 & 1.39 \\
\hline T8 & 16.23 & 14.12 & 8.19 & 38.54 & 2.05 & 2.11 & 1.18 & 1.78 \\
\hline T9 & 16.73 & 14.61 & 8.64 & 39.98 & 1.98 & 1.50 & 1.16 & 1.55 \\
\hline Mean & 15.62 & 13.50 & 7.57 & 36.69 & 1.98 & 1.69 & 0.91 & 1.53 \\
\hline SEM & 0.16 & 0.16 & 0.12 & - & 0.04 & 0.07 & 0.04 & - \\
\hline Significance: & & $P$ value & & - & & $P$ value & & - \\
\hline Treatments & & $<0.001$ & & - & & 0.049 & & - \\
\hline Cuts & & $<0.001$ & & - & & $<0.001$ & & - \\
\hline Interaction & & 0.766 & & - & & $<0.001$ & & - \\
\hline
\end{tabular}

SEM: standard error of the means, $P$ value: probability value.

\section{Chemical composition of NP fertilized sorghum:}

The effect of fertilizer treatments, cut number and their interaction on the chemical composition of sorghum fodder are shown in Table (3). It was shown that all nutrients contents (DM, CP and CF) except EE and NFE were significantly $(\mathrm{P}<0.05)$ affected by NP fertilization levels. However, all nutrients were significantly affected by the number of cutting. The interaction between the two factors (treatments $\mathrm{X}$ cuts) has influenced DM, CP, CF, EE and NFE contents but not on ash contents. The capacity of forage to promote animal production (its feeding value) depends on the chemical composition of nutrients and the amount of forage eaten by the animal (its feeding value). In fodder crops, as the $\mathrm{N}$ fertilizer increased, the 


\section{Kewan et al.}

content of CP increased while CF decreased which could increase palatability and digestibility. On the other hand, the amount of soluble carbohydrates also could alter the quality of the forages (Almodares et. al., 2009). Also, $\mathrm{P}$ is another fundamental nutrient required to increase plant yield. Consequently, the lack of $\mathrm{P}$ is important as the lack of $\mathrm{N}$ in limiting plant performance. Aganga and Autlwetse (2000) reported 91.20, 6.39, and $11.19 \%$ for DM, CP and ash in sorghum, respectively. Chakravarthi et al. (2017) found that the DM content of sorghum fodder changed from 11.82 to $38.19 \%$ with an overall mean estimation of $26.30 \%$ on a DM basis. The mean CP content was $12.42 \%$ and exhibited an average of $15.95 \%$. The total ash content varied from 6.15 to $13.08 \%$ with a mean value of $9.18 \%$. Talpada et al. (2016) found that higher CP (10.78\%) and CF (33.62\%) contents in the sorghum fodder were recorded with NP fertilizers at the rate of $100: 50 \mathrm{~kg} / \mathrm{ha}$ as compared to $9.93 \%$ and $32.29 \%$ for the rate of $80: 40 \mathrm{~kg} / \mathrm{ha}$. From this study, it was inferred that sorghum fodder was nutritionally superior fodder for livestock in scarce rainfall areas. The current result of CP content was nearly close to that recorded for different sorghum varieties by Khanum et al. (2010) which ranged from 8.62 to $12.26 \%$ but higher than that of CF content (18.6-19.7\%). Because of the current fertilization treatments, the ash content was higher than that reported for different sorghum varieties which ranged from 5.86 to $9.10 \%$ (Mahanta and Pachauri, 2005). The current results were within those reported by Fahmy et al. (2010). The corresponding values were 11.8-13.2, 24.9-24.9, 1.65-2.86, 50.75-44.56 and 10.9 -14.5\%, respectively for CP, CF, EE, NFE and ash contents in sorghum bicolor irrigated with two levels of water salinity; 4000 and 7000 ppm total salts, respectively.

Table (3): Chemical composition ( $\%$ on DM basis) for three cuts $\left(1^{\text {st }}, 2^{\text {nd }}\right.$ and $\left.3^{\text {rd }}\right)$ of fertilized sorghum.

\begin{tabular}{|c|c|c|c|c|c|c|c|c|c|c|c|c|c|c|c|c|c|c|}
\hline \multirow{2}{*}{ Treatment } & \multicolumn{3}{|c|}{ DM\% } & \multicolumn{3}{|c|}{ СР\% } & \multicolumn{3}{|c|}{ CF\% } & \multicolumn{3}{|c|}{ EE\% } & \multicolumn{3}{|c|}{ NFE \% } & \multicolumn{3}{|c|}{ Ash\% } \\
\hline & $1^{\text {st }}$ & $2^{\text {nd }}$ & $3^{\text {rd }}$ & $1^{\text {st }}$ & $2^{\text {nd }}$ & $3^{\text {rd }}$ & $1^{\text {st }}$ & $2^{\text {nd }}$ & $3^{\text {rd }}$ & $1^{\text {st }}$ & $2^{\text {nd }}$ & $3^{\text {rd }}$ & $1^{\text {st }}$ & $2^{\text {nd }}$ & $3^{\text {rd }}$ & $1^{\text {st }}$ & $2^{\text {nd }}$ & $3^{\text {rd }}$ \\
\hline T1 & 23.38 & 23.75 & 24.23 & 11.59 & 12.03 & 8.44 & 22.48 & 21.89 & 21.55 & 4.59 & 3.43 & 2.15 & 49.44 & 52.10 & 59.13 & 11.90 & 10.55 & 8.74 \\
\hline $\mathrm{T} 2$ & 24.85 & 24.38 & 24.93 & 9.56 & 15.13 & 9.69 & 22.01 & 23.22 & 22.37 & 3.82 & 3.79 & 1.85 & 52.96 & 47.98 & 57.20 & 11.65 & 9.90 & 8.90 \\
\hline T3 & 25.14 & 25.65 & 24.94 & 11.75 & 13.00 & 10.47 & 23.12 & 24.38 & 22.55 & 4.43 & 3.05 & 1.96 & 48.84 & 49.62 & 56.31 & 11.87 & 9.96 & 8.72 \\
\hline T4 & 23.63 & 24.05 & 23.70 & 14.47 & 11.38 & 8.97 & 23.11 & 23.18 & 22.65 & 4.25 & 3.04 & 1.64 & 46.48 & 51.88 & 58.14 & 11.70 & 10.53 & 8.61 \\
\hline T5 & 25.59 & 25.42 & 24.88 & 12.84 & 10.91 & 9.84 & 24.01 & 21.18 & 23.92 & 4.18 & 3.12 & 2.44 & 49.07 & 55.63 & 54.97 & 9.90 & 9.17 & 8.84 \\
\hline T6 & 25.95 & 25.94 & 24.84 & 11.78 & 10.28 & 9.28 & 22.96 & 22.73 & 23.07 & 5.37 & 3.51 & 1.87 & 49.30 & 54.08 & 57.47 & 10.59 & 9.41 & 8.31 \\
\hline $\mathrm{T} 7$ & 23.89 & 24.34 & 24.48 & 10.72 & 10.59 & 9.53 & 22.57 & 21.65 & 20.57 & 3.82 & 3.32 & 2.59 & 52.32 & 54.91 & 58.84 & 10.58 & 9.54 & 8.47 \\
\hline T8 & 25.93 & 26.15 & 25.02 & 13.00 & 10.00 & 9.44 & 25.47 & 23.71 & 22.29 & 3.72 & 2.98 & 2.36 & 46.01 & 53.79 & 57.79 & 11.80 & 9.53 & 8.14 \\
\hline T9 & 26.23 & 26.29 & 25.57 & 12.25 & 11.66 & 10.19 & 24.40 & 21.43 & 23.26 & 3.62 & 3.63 & 2.69 & 47.74 & 54.11 & 55.68 & 12.00 & 9.18 & 8.19 \\
\hline Mean & 24.95 & 25.11 & 24.73 & 12.00 & 11.66 & 9.54 & 23.34 & 22.59 & 22.47 & 4.20 & 3.32 & 2.17 & 49.13 & 52.68 & 57.28 & 11.33 & 9.75 & 8.54 \\
\hline SEM & 0.19 & 0.18 & 0.11 & 0.31 & 0.30 & 0.13 & 0.23 & 0.25 & 0.19 & 0.11 & 0.06 & 0.10 & 0.49 & 0.48 & 0.29 & 0.18 & 0.10 & 0.06 \\
\hline Significance: & & $P$ value & & & P value & & & $P$ value & & & $P$ value & & & $P$ value & & & P value & \\
\hline Treatments & & 0.041 & & & 0.038 & & & 0.034 & & & 0.746 & & & 0.302 & & & 0.017 & \\
\hline Cuts & & 0.017 & & & 0.001 & & & 0.001 & & & 0.001 & & & 0.001 & & & 0.001 & \\
\hline Interaction & & 0.019 & & & 0.001 & & & 0.079 & & & 0.007 & & & 0.003 & & & 0.305 & \\
\hline
\end{tabular}

\section{Hydrocyanic acid and nitrate concentration:}

Anti-nutritional factors like tannin, nitrates and silica of salt-tolerant fodders could restrict animals feeding mainly when they are separately used as a sole diet (Helal et al., 2018). At feeding animals, these compounds in fodders form insoluble complexes with nutrients (proteins, carbohydrates and minerals) bringing down the feeding values of the fodders. Sorghum contains two major secondary metabolites; tannin, a polyphenolic compound located in the grain and, dhurrin, a cyanogenic glucoside located mainly in the aerial shoot and sprouted seeds (Sher et al., 2011). Forage sorghum may have some risk of toxicity to animals, especially when grazed at an early stage of fodder growth as toxicities can result from glucoside dhurrin (Conn, 1993). Disruption of the plant tissue allows the glucoside found in the epidermal tissue to mix with the enzymes occurring in either the mesophyll tissue or in rumen fluid then the HCN is released (Majak et al., 1990). This may cause lethal harming of animals and more commonly avoiding sulfur insufficiency (Wheeler et al., 1980). This may be the constraint of usage of sorghum for grazing while it is still young and digestible.

Figure (1) showed that sorghum hydrocyanic acid content (mg/100g DM) was higher in the third cut compared to the second and first cuttings, respectively. Additionally, higher total HCN contents in 
sorghum fodder with the application of T1, T2 and T3 and lowest rates of T4 through T9. In this regard, T3 showed the unsafe limit of HCN content particularly for second and third cuts. Similar results were found by Obour et al. (2018). Wheeler et al. (1980) reported that the hydrocyanic (HCN) potential (mean $0.04 \%$ ) in forage sorghum was increased by $28 \%$ as $\mathrm{N}$ fertilizer and reduced by $34 \%$ as $\mathrm{P}$ application. Therefore, the $\mathrm{P}$ diminished the dangers related to $\mathrm{HCN}$ particularly at an early growth stage, when such dangers are most dreaded (Sher et al., 2011). Likewise, Sarfraz et al. (2012) and Karthika and Kalpana (2017) indicated that the safe limit of $\mathrm{HCN}$ in green forage for livestock is $500 \mathrm{ppm}$ on a fresh weight basis. Hence, all treatments except T3 may produce suitable feed to the animals because of its lower content of HCN than the permissible limits.

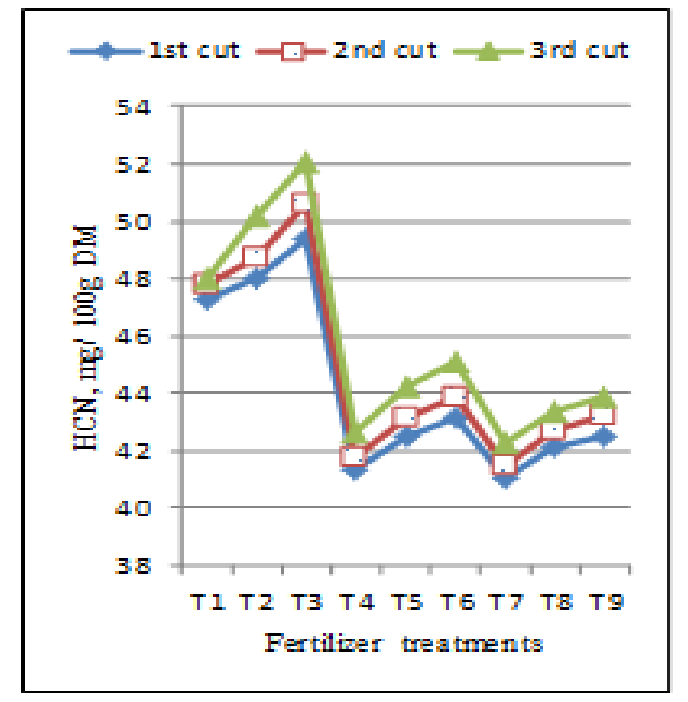

Fig.(1): HCN concentration in sorghum
fertilized with different levels of NP
(Poisonous level $=50 \mathrm{mg} / 100 \mathrm{gDM}$ ).

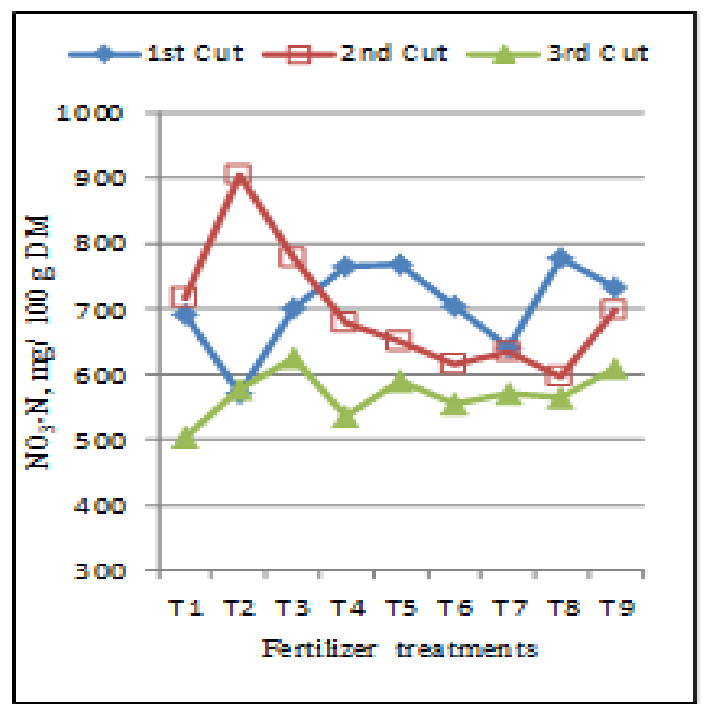

Fig.(2): Nitrate concentration in sorghum fertilized with different levels of NP (Poisonous level $=800 \mathrm{mg} / 100 \mathrm{gDM}$ ).

Figure (2) showed that only the second cut of T2 revealed higher nitrate content than the safe limit reported by Obour et al. (2018). The aggregation of nitrate in plants does not necessarily mean that a problem will happen. Realizing how to manage the harvesting and feeding of a feed that contains nitrate will reduce possible problems in a livestock operation. Obour et al. (2018) inferred the validity of fodders in terms of the presence of nitrates into three categories. First, forage containing 3,000 ppm nitrates is generally considered safe as livestock feed. Second, nitrate concentrations between 3,000 and 6,000 ppm may be limit-fed. Third, concentrations above 9,000 ppm should not be fed to livestock. Al Khalasi et al. (2010) reported that rumen micro-organisms could convert nitrate into nitrite and finally to ammonia. Besides, the microbes can adapt to a constant level of nitrate in the feed and make the nitrate conversion cycle more efficient. It takes 3 to $5 \mathrm{~d}$ for the microbes to adjust to the new rumen conditions, and once adjusted, the conversion increases in capacity by three to five times (above normal levels). During the acclimation period, some of the microbes will vanish, and the rate of digestion will slow down (Al Khalasi et al., 2010). Once the microbial populations recover to normal levels, digestion rates also return to normal. The faster an animal consumes feed containing nitrates, the faster the rate of nitrate release. Dry hay contains less water than fresh forage and is consumed more quickly (on a dry basis). Also, nitrate is released from dry hay more rapidly than from a fresh forage into the rumen because cell walls in the hay are ruptured during drying, allowing for a rapid release of cell contents. About $30 \%$ of the nitrate in fresh forage is released in twenty minutes while $80 \%$ of the nitrate is released from dry hay at the same time.

\section{Calcium, phosphorus concentration and their ratio:}

The data presented in Table (4) showed that $\mathrm{Ca}, \mathrm{P}$ and their ratio contents in the fodder of sorghum are significantly differed due to the experimental factors (NP rate and the cut number and their interaction). The mean values of $\mathrm{Ca}, \mathrm{P}$ and their ratio contents of the different sorghum treatments ranged between $0.54-0.88 \%, 0.54-0.59 \%$ and $0.94-1.51$, respectively. These results are different from that reported by Aganga and Autlwetse (2000) that were 0.12 and $0.21 \%$ for $\mathrm{Ca}$ and $\mathrm{P}$ content, respectively. This 


\section{Kewan et al.}

difference may be due to differences in treatments and/ or the type of soil. Complex interactions between minerals may be predisposed to mineral imbalance when animals fed salt-tolerant fodders alone (Masters et al., 2007). Al Khalasi et al. (2010) found that Ca and P contents were 5170-6060-5650 and 706-828$661 \mathrm{mg} / 100 \mathrm{~g}$ for sorghum irrigated with saline water at levels of 3, 6 and $9 \mathrm{dS} / \mathrm{m}$, respectively.

Table (4): Calcium and phosphorus concentrations.

\begin{tabular}{|c|c|c|c|c|c|c|c|c|c|c|c|c|}
\hline \multirow{3}{*}{ Treatments } & \multicolumn{3}{|c|}{ Calcium \% } & \multirow{3}{*}{$\mathrm{M}$} & \multicolumn{3}{|c|}{ Phosphorus \% } & \multirow{3}{*}{ M } & \multicolumn{3}{|c|}{$\mathrm{Ca}: \mathrm{P}$ ratio } & \multirow{3}{*}{ M } \\
\hline & $1^{\text {st }}$ & $2^{\text {nd }}$ & $3^{\text {rd }}$ & & $1^{\mathrm{st}}$ & $2^{\text {nd }}$ & $3^{\mathrm{rd}}$ & & $1^{\text {st }}$ & $2^{\text {nd }}$ & $3^{\mathrm{rd}}$ & \\
\hline & cut & cut & cut & & cut & cut & cut & & cut & cut & cut & \\
\hline $\mathrm{T} 1$ & 0.46 & 1.00 & 1.15 & 0.87 & 0.40 & 0.63 & 0.65 & 0.56 & 1.15 & 1.59 & 1.78 & 1.51 \\
\hline $\mathrm{T} 2$ & 0.42 & 0.93 & 1.15 & 0.83 & 0.45 & 0.51 & 0.72 & 0.56 & 0.92 & 1.83 & 1.60 & 1.45 \\
\hline $\mathrm{T} 3$ & 0.41 & 1.03 & 1.21 & 0.88 & 0.44 & 0.60 & 0.71 & 0.58 & 0.93 & 1.71 & 1.70 & 1.45 \\
\hline $\mathrm{T} 4$ & 0.40 & 0.95 & 0.54 & 0.63 & 0.45 & 0.63 & 0.70 & 0.59 & 0.89 & 1.51 & 0.77 & 1.06 \\
\hline $\mathrm{T} 5$ & 0.44 & 0.92 & 0.55 & 0.64 & 0.50 & 0.58 & 0.65 & 0.58 & 0.88 & 1.59 & 0.85 & 1.11 \\
\hline T6 & 0.43 & 1.11 & 0.48 & 0.67 & 0.46 & 0.53 & 0.70 & 0.56 & 0.93 & 2.08 & 0.68 & 1.23 \\
\hline $\mathrm{T} 7$ & 0.42 & 0.69 & 0.52 & 0.54 & 0.46 & 0.61 & 0.67 & 0.58 & 0.90 & 1.14 & 0.78 & 0.94 \\
\hline $\mathrm{T} 8$ & 0.44 & 1.11 & 0.50 & 0.68 & 0.46 & 0.50 & 0.67 & 0.54 & 0.96 & 2.22 & 0.75 & 1.31 \\
\hline T9 & 0.53 & 1.01 & 0.53 & 0.69 & 0.52 & 0.49 & 0.72 & 0.58 & 1.02 & 2.05 & 0.74 & 1.27 \\
\hline Mean & 0.44 & 0.97 & 0.73 & - & 0.46 & 0.56 & 0.69 & - & 0.95 & 1.76 & 1.09 & - \\
\hline SEM & 0.01 & 0.03 & 0.06 & - & 0.01 & 0.01 & 0.01 & - & 0.02 & 0.07 & 0.09 & - \\
\hline Significance & \multicolumn{3}{|c|}{$\mathrm{P}$ value } & - & \multicolumn{3}{|c|}{$\mathrm{P}$ value } & - & \multicolumn{3}{|c|}{$\mathrm{P}$ value } & - \\
\hline Treatments & \multicolumn{3}{|c|}{$<0.001$} & - & \multicolumn{3}{|c|}{0.025} & - & \multicolumn{3}{|c|}{$<0.001$} & - \\
\hline Cuts & \multicolumn{3}{|c|}{$<0.001$} & - & \multicolumn{3}{|c|}{$<0.001$} & - & \multicolumn{3}{|c|}{$<0.001$} & - \\
\hline Interaction & \multicolumn{3}{|c|}{$<0.001$} & - & \multicolumn{3}{|c|}{0.006} & - & \multicolumn{3}{|c|}{$<0.001$} & - \\
\hline
\end{tabular}

M: mean; SEM: standard error of the means, $P$ value: probability value.

\section{In situ and in vitro gas production evaluation:}

The results of evaluating the ISDMD of successive cuts and the in vitro gas parameters of composted samples of each treatment are shown in Table (5). It was found that mean values of ISDMD were higher for T6 up to T9 as compared to the other treatments. A similar pattern was observed in in vitro gas production parameters. Concerning the impact of treatments on in vitro $\mathrm{OM}$ digestibility and $\mathrm{MCP}$, the values found to range from 46.72 to $59.75 \%$ and 56.37 to $70.10 \mathrm{~g} / \mathrm{kg}$ DOM, respectively. Additionally, $\mathrm{ME}$ and $\mathrm{NEg}$ ranged from 8.15 to $9.95 \mathrm{MJ} / \mathrm{kg} \mathrm{DM}$ and 4.21 to $5.25 \mathrm{MJ} / \mathrm{kg} \mathrm{DM}$, respectively. The differences in $\mathrm{ME}$ of various treatments reflect different contents of available $\mathrm{N}$ and fermentable carbohydrates. Such differences in digestibility and ME of sorghum could be due to differences in their chemical composition. In general, evaluating the treated sorghum with considering into account the feeding value as predicted NEg value and the cost of treatment resulted in both T6 and T8 were suitable diets for growing lambs as compared to T1. The high gas yield in T6, T8 and T9 as compared to T1 probably resulted from high soluble $\mathrm{CP}$ and supply of $\mathrm{N}$ required for growth of microorganism as well as high ruminal fermentation capacity for structural and nonstructural carbohydrate (Piri et al., 2012). The correlations between the results of both methodologies (in situ and in vitro gas yield) seem to be sufficiently strong (Khan et al., 2007) where the relationship between DM and GP values for three cuts of alfalfa was about $0.89,0.85$ and 0.84 . Heseen et al. (2017) found that gas production, OM digestibility and ME parameters of different cuts of forage sorghum cultivars as affected by different organic and mineral treatments ranged from 23.72 to $27.92 \mathrm{ml} / 200 \mathrm{mg} \mathrm{DM}$, and from 50.77 to $54.41 \%$ and $4.98-5.78$ $\mathrm{MJ} / \mathrm{kg} \mathrm{DM}$, respectively. On the other hand, Pholsen and Suksri (2004) showed that the application of chemical fertilizer plus organic amendment has no significant effect on DM digestibility. Singh et al. (2017) found the in vitro microbial mass for different varieties of sorghum stover in sheep to be ranged from 201 to $307 \mathrm{mg} / \mathrm{g}$ DM. Besides, the ME and NEg contents were 5.01-7.04 KJ/ g DM and 0.41-1.04 $\mathrm{KJ} / \mathrm{g}$ DM. Otherwise, methane production was 16.2 to $32.3 \mathrm{ml} / \mathrm{g} \mathrm{DM}$. Also, Wang et al. (2021) reported higher values of efficiency of microbial protein synthesis in sheep fed sorghum silage or hay with and without grape seed addition which ranged from 94.4 to $120.9 \mathrm{~g} \mathrm{MCP} / \mathrm{kg}$ DOMI. 
Table (5): In situ DM degradability at $72 \mathrm{~h}$ and gas production parameters for sorghum forages.

\begin{tabular}{|c|c|c|c|c|c|c|c|c|c|c|}
\hline \multirow{2}{*}{ Treatment } & \multicolumn{3}{|c|}{$I S D M D(\%)$ at $72 \mathrm{~h}^{1}$} & \multirow{2}{*}{ Mean } & \multicolumn{6}{|c|}{ Gas production parameters $^{2}$} \\
\hline & $1^{\text {st }}$ cut & $2^{\text {nd }}$ cut & $3^{\text {rd }}$ cut & & GV & $\mathrm{CH}_{4}$ & DOM & MCP & $\mathrm{ME}$ & $\mathrm{NEg}$ \\
\hline $\mathrm{T} 1$ & 39.93 & 37.28 & 35.33 & 37.51 & 36.94 & 5.47 & 46.72 & 56.37 & 8.15 & 4.21 \\
\hline $\mathrm{T} 2$ & 41.52 & 40.68 & 38.88 & 40.36 & 38.14 & 5.54 & 47.96 & 57.87 & 8.31 & 4.30 \\
\hline $\mathrm{T} 3$ & 45.73 & 43.86 & 42.09 & 43.89 & 39.18 & 5.89 & 49.02 & 59.14 & 8.47 & 4.39 \\
\hline $\mathrm{T} 4$ & 46.09 & 44.20 & 40.89 & 43.71 & 43.25 & 5.62 & 53.08 & 64.04 & 8.98 & 4.69 \\
\hline T5 & 40.76 & 38.97 & 45.00 & 41.58 & 46.22 & 5.66 & 56.00 & 67.57 & 9.41 & 4.94 \\
\hline T6 & 48.78 & 46.19 & 44.99 & 46.65 & 50.01 & 5.66 & 59.75 & 72.08 & 9.95 & 5.25 \\
\hline $\mathrm{T} 7$ & 45.95 & 44.31 & 42.76 & 44.34 & 47.12 & 5.67 & 56.85 & 68.59 & 9.48 & 4.98 \\
\hline T8 & 46.46 & 51.09 & 48.77 & 48.77 & 48.34 & 5.68 & 58.11 & 70.10 & 9.64 & 5.07 \\
\hline T9 & 45.62 & 47.55 & 46.46 & 46.54 & 48.21 & 5.68 & 58.01 & 69.99 & 9.70 & 5.11 \\
\hline Mean & 44.54 & 43.79 & 42.80 & 43.71 & 44.16 & 5.65 & 53.95 & 65.08 & 9.12 & 4.77 \\
\hline SEM & 1.01 & 1.44 & 1.36 & 0.73 & 1.65 & 0.04 & 1.64 & 1.98 & 0.22 & 0.13 \\
\hline Pvalue & - & - & - & 0.04 & 0.009 & 0.005 & 0.018 & 0.007 & 0.01 & 0.014 \\
\hline
\end{tabular}

${ }^{I S D M D:}$ In situ DM degradability.

${ }^{2} \mathrm{GV}$ : gas volume (ml), CH4: methane volume (ml), DOM: digestible organic matter (\%), MCP: microbial protein (g/kg DOM), ME: metabolizable energy (MJ/kg DM), NEg: net energy for growth (MJ/kg DM).

$P$ value: probability value

\section{Chemical composition of the experimental rations:}

The chemical composition of green forages and concentrate feed mixture (CFM) are presented in Table (6). The CP, CF and ash concentration of sorghum T1 (control) were the lowest compared with the other treatments (T6 and T8) but the opposite trend was observed for NFE\%.

Table (6): Chemical composition (\%) of feeds and experimental rations fed to Barki lambs.

\begin{tabular}{|c|c|c|c|c|c|c|c|c|c|}
\hline Item & DM & $\mathrm{CP}$ & $\mathrm{CF}$ & $\mathrm{EE}$ & NFE & Ash & $\mathrm{Ca}$ & $\mathrm{P}$ & Ca: P \\
\hline $\mathrm{CFM}^{1}$ & 91.12 & 13.67 & 12.11 & 4.71 & 64.29 & 5.22 & 1.56 & 0.87 & 1.79 \\
\hline $\mathrm{T} 1$ & 23.23 & 9.10 & 21.56 & 3.39 & 56.56 & 9.39 & 0.71 & 0.49 & 1.45 \\
\hline T6 & 24.11 & 11.35 & 23.67 & 2.44 & 52.19 & 10.35 & 0.62 & 0.58 & 1.07 \\
\hline $\mathrm{T} 8$ & 25.70 & 11.05 & 23.72 & 2.98 & 52.13 & 10.12 & 0.69 & 0.62 & 1.11 \\
\hline \multicolumn{10}{|c|}{ Calculated rations ${ }^{2}$ : } \\
\hline R1-Control & 46.77 & 12.19 & 15.18 & 4.28 & 61.78 & 6.57 & 1.28 & 0.75 & 1.72 \\
\hline $\mathrm{R} 2$ & 47.35 & 12.90 & 15.95 & 3.95 & 60.27 & 6.93 & 0.68 & 0.77 & 0.88 \\
\hline R3 & 47.78 & 12.74 & 16.25 & 4.09 & 59.96 & 6.97 & 0.64 & 0.78 & 0.83 \\
\hline
\end{tabular}

The calculated rations (Table 6) showed similar percentages of contents except the $\mathrm{Ca}$ and $\mathrm{Ca}$ : $\mathrm{P}$ ratio contents which were higher in T1 than that in T6 and T8. Helal et al. (2018) found that S. bicolor recorded contents of DM, CP, CF, EE, NFE and ash to be 92.17, 8.08, 22.99, 1.69, 53.53 and 13.71\%, respectively. 


\section{Kewan et al.}

\section{Growth performance of Barki lambs:}

Live body weights at the initial experiment of three groups were almost equivalent (Table 7). The final body weights of all experimental groups were significantly $(\mathrm{P}<0.05)$ different. Average daily gain $(\mathrm{ADG})$ was significantly $(\mathrm{P}<0.05)$ affected by the experimental rations being values; 158, 185 and 192 $\mathrm{g} / \mathrm{h} / \mathrm{d}$ for lamb groups fed R1, R2 and R3, respectively. The daily gain in this study was almost comparable with that obtained in lambs fed ration containing Sesbania-Sorghum mixture (1:1) + CFM which ranged between 132.5 and 175.5 with an average of $154 \mathrm{~g} / \mathrm{d}$ (Zaki et al., 2015). What's more, the sorghum intake by rams was 530 and $640 \mathrm{~g} \mathrm{DM} / \mathrm{head} / \mathrm{d}$ from the $1^{\text {st }}$ and the $2^{\text {nd }}$ cuts, respectively. In comparison with the current results, the higher feed intake was because of predominantly the lower CFM offered which was half of the total CP requirement. Furthermore, Al Khalasi et al. (2010) found that lambs fed diets containing sorghum fodder irrigated with three different concentrations of salt water (3, 6 and $9 \mathrm{dS} / \mathrm{m}$ ) grew well throughout the trial period and achieved body weight gain between 68.2 and 96.3 g/day. The ADG of lambs fed sweet sorghum silage + grape seed (SSG) was greater (217g) than lambs fed sweet sorghum hay (SH) (161g) and tended to be greater than sweet sorghum (SS) group (192g), whereas sweet sorghum hay + grape seed (SHG) group tended to be greater (183g) than SH group (Wang et al., 2021).

Concerning data of feed intake (Table 7), there were no differences $(\mathrm{P}<0.05)$ in concentrate intake between animal groups. However, sorghum intake and total feed intake were significantly $(\mathrm{P}<0.05)$ affected by the experimental rations and both R2 and R3 groups consumed higher amounts compared with the control one. With calculating the relative daily sorghum intake to body weight or total feed intake, the corresponding relating esteems were $1.10,1.15,1.29 \%$ and $32.44,33.27,35.63 \%$ for $\mathrm{T} 1$, T2 and $\mathrm{T} 3$, respectively.

Table (7): Growth performance and feed utilization in Barki lambs (Period 85d).

\begin{tabular}{lccc|ccc|ccc}
\hline Item & \multicolumn{3}{c}{ Body weight } & \multicolumn{3}{c}{ Feed intake as DM } & \multicolumn{3}{c}{ Feed conversion } \\
\cline { 2 - 10 } & IBW & FBW & ADG & CFM & Sorghum & Total & DM & TDN & DCP \\
& $(\mathrm{Kg})$ & $(\mathrm{Kg})$ & $(\mathrm{g} / \mathrm{d})$ & $(\mathrm{g})$ & $(\mathrm{g})$ & $(\mathrm{g})$ & $(\mathrm{g} / \mathrm{g})$ & $(\mathrm{g} / \mathrm{g})$ & $(\mathrm{g} / \mathrm{g})$ \\
\hline R1- Control & 22.23 & $35.66^{\mathrm{b}}$ & $158^{\mathrm{b}}$ & 670 & $322^{\mathrm{c}}$ & $992^{\mathrm{c}}$ & $6.28^{\mathrm{a}}$ & $4.44^{\mathrm{a}}$ & $0.512^{\mathrm{b}}$ \\
R2 & 23.00 & $38.73^{\mathrm{a}}$ & $185^{\mathrm{a}}$ & 710 & $354^{\mathrm{b}}$ & $1064^{\mathrm{b}}$ & $5.75^{\mathrm{b}}$ & $4.10^{\mathrm{b}}$ & $0.529^{\mathrm{a}}$ \\
R3 & 22.50 & $38.79^{\mathrm{a}}$ & $192^{\mathrm{a}}$ & 715 & $396^{\mathrm{a}}$ & $1111^{\mathrm{a}}$ & $5.80^{\mathrm{b}}$ & $4.18^{\mathrm{b}}$ & $0.535^{\mathrm{a}}$ \\
\hline SEM & 0.29 & 0.29 & 2.91 & 16.14 & 24.64 & 38.27 & 0.26 & 0.19 & 0.06 \\
P value & 0.685 & 0.036 & 0.016 & 0.615 & 0.042 & 0.023 & 0.033 & 0.009 & 0.021
\end{tabular}

IBW: initial body weight, FBW: final body weight, ADG: average daily gain, CFM: concentrate feed mixture, TDN: total digestible nutrients, DCP: digestible crude protein, SEM: standard error of the means, $P$ value: probability value. Means in the same line with different superscripted letters $(a, b$ and $c)$ are significantly different $(P<0.05)$.

The sorghum intake expressed as g DM/ kg BW were 11.1, 11.5 and 12.9 for R1, R2 and R3 groups, respectively. These values were lower than that reported by Fahmy et al. (2010) which were 22.9 and 19.6 for sheep fed sole diets based on sorghum irrigated with two salinity levels. In the current study lambs fed $\mathrm{R} 1$ ration (low in $\mathrm{P}$ and/or $\mathrm{N}$ ) consumed less food, produced less rumen microbial protein and grew at slower rates than those fed a diet rich in these nutrients and these results were in accordance with that found by Scott et al. (1997). Wang et al. (2021) reported values of DM intake to be 699.0, 661.5, 529.0 and $614.2 \mathrm{~g} / \mathrm{d}$ for lambs fed SS, SSG, SH and SHG diets, respectively.

There is also a significant impact $(\mathrm{P}<0.05)$ of sorghum treatments on feed conversion ratio (Table 7$)$, where sheep fed R2 or R3 ration had better feed conversion ratio as $\mathrm{g}$ DM/ g gain or $\mathrm{g}$ TDN/ $g$ gain than those fed control sorghum ration. However, control group (R1) revealed better feed conversion as $g$ $\mathrm{DCP} / \mathrm{g}$ gain when compared with the other groups. Feed conversion in this study was lower than that recorded for lambs fed a ration containing sesbania-sorghum mixture (1:1) + CFM which was $7.63 \mathrm{~kg}$ DMI/ kg gain (Zaki et al., 2015). Wang et al. (2021) reported a range from 6.01 to $6.76 \mathrm{~g} \mathrm{DM} / \mathrm{g}$ gain as feed conversion of diets including sorghum as a silage or hay form. 


\section{Digestibility and nutritive values:}

Data in Table (8) summarized results of the digestibility of nutrients and also the nutritive values of the experimental rations. The current results of digestibility for $\mathrm{CP}$ and $\mathrm{CF}$ were within the range recorded for different sorghum varieties by Khanum et al. (2010) which were 63.5-74.9\% for CP and 64.5-73.5\% for $\mathrm{CF}$ but higher than that for DM digestibility (55.1-61.9\%). Fahmy et al. (2010) reported the digestibility of sorghum nutrients to be 58.2, 64.5, 60.7, 75.9 and 59.3\% for DM, CP, CF, EE and NFE, respectively. In addition, they found the TDN and DCP values to be 57.7 and $9.76 \%$, respectively. Sheridan et al. (2003) showed that sorghum was in a low digestibility by sheep as compared to lucerne however, the daily growth rate of lambs versus adult sheep grazing sorghum-Sudan grass hybrids was 84 vs. $87 \mathrm{~g} / \mathrm{d}$, respectively. Besides, Talpada et al. (2016) inferred that sorghum fodder contains more than $50 \%$ TDN with $8 \% \mathrm{CP}, 2.5 \% \mathrm{EE}$ and $45 \% \mathrm{NFE}$ and its nutritional value is equivalent to that of corn. The digestibility of DM ranged from 64.9 to $69.5 \%$ for sweet sorghum as silage or hay form with or without grape seed supplementation (Wang et al., 2021). Singh et al. (2017) found the digestibility of DM and CP ranged from 51 to $54 \%$ and 51 to $56 \%$ for different varieties of sorghum stover in sheep but the DCP value ranged from 45 to $67 \%$.

Zaki et al. (2015) found that lambs fed a ration containing Sesbania-Sorghum mixture $(1: 1)+$ CFM, resulted in digestibility values to be $56.81,73.60,51.93,71.42$, and $63.10 \%$, for DM, CP, CF, EE and NFE, respectively. They added that the TDN was 61.68 and $65.20 \%$ for the $1^{\text {st }}$ cut and $2^{\text {nd }}$ cut of sorghum, respectively and it was 11.89 and $10.95 \%$ for DCP, respectively.

Digestibilities of EE and NFE were in accordance with that found by Ward et al. (2001) who concluded that digestibility of EE was comparable among different varieties of sorghum silage. They found also, the digestibilities of various nutrients were similar in various species of animals fed on sorghum forage exclusively or mixed ration of forage and concentrates. Also, Al Khalasi et al. (2010) found no differences in the digestibilities of $\mathrm{CP}, \mathrm{EE}$ and fiber components (NDF and ADF) between sorghum-based diets.

Table (8): Digestibility of nutrients and feeding values of rations fed to Barki lambs.

\begin{tabular}{lcccccccc}
\hline \multirow{2}{*}{ Item } & \multicolumn{4}{c}{ Digestibility coefficient (\%) } & & \multicolumn{2}{c}{ Nutritive value (\%) } \\
\cline { 2 - 5 } & DM & CP & CF & EE & NFE & & TDN & DCP \\
\hline R1-Control & $66.88^{\mathrm{b}}$ & $66.88^{\mathrm{c}}$ & $60.00^{\mathrm{c}}$ & 76.51 & 74.58 & & $70.70^{\mathrm{b}}$ & $8.15^{\mathrm{b}}$ \\
R2 & $67.36^{\mathrm{a}}$ & $71.36^{\mathrm{b}}$ & $63.09^{\mathrm{b}}$ & 78.95 & 74.64 & & $71.28^{\mathrm{a}}$ & $9.20^{\mathrm{a}}$ \\
R3 & $68.48^{\mathrm{a}}$ & $72.51^{\mathrm{a}}$ & $64.95^{\mathrm{a}}$ & 77.70 & 75.21 & & $72.04^{\mathrm{a}}$ & $9.24^{\mathrm{a}}$ \\
\hline SEM & 0.15 & 0.29 & 0.31 & 0.66 & 0.35 & & 0.19 & 0.11 \\
P value & 0.025 & 0.037 & 0.046 & 0.441 & 0.276 & & 0.034 & 0.031 \\
\hline
\end{tabular}

SEM: standard error of the means, $P$ value: probability value.

Means in the same line with different superscripted letters $(a, b$ and $c)$ are significantly different $(P<0.05)$.

\section{Balance of nitrogen, calcium and phosphorus:}

Either $\mathrm{N}$ intake or urine- $\mathrm{N}$ was significantly $(\mathrm{P}<0.05)$ affected by the experimental diets as shown in Table (9). All the experimental lambs revealed a positive $\mathrm{N}$ balance. Lower fecal $\mathrm{N}$ loss and higher $(\mathrm{P}<0.05) \mathrm{N}$ balance were observed in $\mathrm{R} 2$ than the control group. Higher $\mathrm{N}$ balance in the present study may be due to comparatively higher DMI as well as higher $\mathrm{N}$ content and also increased ruminal $\mathrm{N}$ pool and post-ruminal amino acid flow (Thota et al., 2017). Contrary, Hernandez et al. (2009) observed that Nintake, fecal-N, urinary $\mathrm{N}$ and $\mathrm{N}$-retention were not affected in lambs fed with orchard grass hay as basal diet. The revealed NB values were nearly close to that found by Wang et al. (2021) which ranged from 6.82 to $8.02 \mathrm{~g} / \mathrm{d}$ for lambs fed diets based on sorghum fodder. However, Al Khalasi et al. (2010) reported lower range value $(4.5$ to $5.1 \mathrm{~g} / \mathrm{d}$ ) for sheep fed diets based on sorghum irrigated with saline water at levels of 3, 6 and $9 \mathrm{dS} / \mathrm{m}$. Also, Singh et al. (2017) found the NB in sheep fed different varieties of sorghum stover, ranged from 1.07 to $2.29 \mathrm{~g} / \mathrm{d}$. In the current study, the animal groups retained $\mathrm{N}$ by about 33.7, 35.6 and $35.5 \%$ of $\mathrm{N}$ intake for $\mathrm{R} 1, \mathrm{R} 2$ and $\mathrm{R} 3$, respectively. These values were within that for lambs received diets of sorghum silage (9.46 to 36.44\%) as recorded by Mahanta and Pachauri (2005). Also, Fahmy et al. (2010) found NB to be $212 \mathrm{mg} / \mathrm{kg}$ BW and represented $33.6 \%$ of $\mathrm{N}$ intake by lambs fed sorghum hay. The biological value of $\mathrm{N}(=\mathrm{NB} \times 100 /(\mathrm{NI}-\mathrm{FN}))$ was calculated to be 50.31, 49.90 and $48.96 \%$ for R1, R2 and R3, respectively. 


\section{Kewan et al.}

Concerning $\mathrm{Ca}$ utilization data (Table 9), it pointed out that both $\mathrm{Ca}$ intake and fecal $\mathrm{Ca}$ were significantly $(\mathrm{P}<0.05)$ affected by the experimental diets. Although, higher significant $\mathrm{Ca}$ intake and excrete via feces in both $\mathrm{R} 1$ and $\mathrm{R} 2$ groups as compared with control, all the lambs retained relatively similar amounts of calcium. These finding may because of high availability of $\mathrm{Ca}$ where the amount of $\mathrm{Ca}$ retained as a relative to that level recommended by Kearl (1982) represent about 171.4, 148.7 and 174.0 $\%$, for $\mathrm{T} 1, \mathrm{~T} 2$ and $\mathrm{T} 3$ groups, respectively.

It was interesting to notice higher $\mathrm{P}$ content in sorghum of R2 and R3 revealed significantly $(\mathrm{P}<0.05)$ higher $\mathrm{P}$ intake and also $\mathrm{P}$ retained (Table 9). This may be attributed to improving nutrient digestibility and ruminal digestion more likely fiber degradation and lower excretion of the minerals (Thota et al., 2017). It seems that $P$ is excreted mainly in feces, which is composed of unabsorbed dietary $P$ and endogenous $\mathrm{P}$ that are confirmed from saliva, digestive juices and intestinal cells. Otherwise, total $\mathrm{P}$ excretion in feces depends largely on P intake (Louvandini and Vitti, 2007). High intake of electrolytes is accompanied by their high excretion through the kidneys (Shaker et al., 2008). The amount of $\mathrm{P}$ retained as a relative to that level recommended by Kearl (1982) represents about 89.3, 105.0 and 110.1\%, for T1, T2 and T3 groups, respectively, which was in harmony with the ADG revealed in the same groups.

Table (9): Balance (g/ head/d) of nitrogen (N), calcium (Ca) and phosphorus (P) in lambs fed the experimental rations

\begin{tabular}{|c|c|c|c|c|c|c|c|c|c|c|c|c|}
\hline \multirow{2}{*}{ Items } & \multicolumn{3}{|c|}{$\mathrm{N}$} & \multirow{2}{*}{ Bal. } & \multicolumn{3}{|c|}{$\mathrm{Ca}$} & \multirow{2}{*}{ Bal. } & \multicolumn{3}{|c|}{$\mathrm{P}$} & \multirow{2}{*}{ Bal. } \\
\hline & Intake & Feces & Urine & & Intake & Feces & Urine & & Intake & Feces & Urine & \\
\hline $\mathrm{R} 1$ & $19.34^{\mathrm{b}}$ & 6.40 & $6.42^{\mathrm{c}}$ & $6.51^{c}$ & $12.74^{\mathrm{c}}$ & $5.42^{\mathrm{b}}$ & 1.51 & 5.81 & $7.41^{b}$ & $4.09^{c}$ & $0.31^{b}$ & $3.01^{\mathrm{c}}$ \\
\hline $\mathrm{R} 2$ & $21.96^{\mathrm{a}}$ & 6.29 & $7.85^{\mathrm{b}}$ & $7.82^{b}$ & $13.27^{\mathrm{a}}$ & $6.70^{\mathrm{a}}$ & 1.53 & 5.04 & $8.23^{\mathrm{a}}$ & $4.40^{\mathrm{b}}$ & $0.29^{c}$ & $3.54^{\mathrm{b}}$ \\
\hline R3 & $22.64^{\mathrm{a}}$ & 6.22 & $8.37^{\mathrm{a}}$ & $8.04^{\mathrm{a}}$ & $13.88^{b}$ & $6.50^{\mathrm{a}}$ & 1.48 & 5.90 & $8.67^{\mathrm{a}}$ & $4.59^{\mathrm{a}}$ & $0.37^{\mathrm{a}}$ & $3.71^{\mathrm{a}}$ \\
\hline SEM & 0.17 & 0.12 & 0.25 & 0.19 & 0.10 & 0.11 & 0.16 & 0.13 & 0.10 & 0.09 & 0.02 & 0.09 \\
\hline P val. & 0.019 & 0.215 & 0.031 & 0.049 & 0.037 & 0.048 & 0.445 & 0.097 & 0.045 & 0.029 & 0.021 & 0.037 \\
\hline
\end{tabular}

Bal: balance; SEM: standard error of the means, $P$ val.: probability value.

Means in the same line with different superscripted letters $(a, b$ and $c)$ are significantly different $(P<0.05)$.

\section{Water utilization:}

Water utilization by lambs is illustrated in Table (10). Data are mainly related to the metabolic body mass $\left(\mathrm{W}^{0.82}\right)$ and indicated that animals fed T2 and T3 rations consumed water more $(\mathrm{P}<0.01)$ than those fed a control ration (153.1 and $154.4 v s .119 .4 \mathrm{~g} / \mathrm{kg}^{0.82}$, respectively), this may be related to higher intakes of DM (Kewan et al., 2011), ash (Kewan et al., 2019) as well as CP (Allam et al., 2009). Fecal and total

Table (10). Water utilization $\left(\mathrm{g} / \mathrm{kg}^{0.82}\right)$ in Barki lambs fed the experimental rations.

\begin{tabular}{|c|c|c|c|c|c|c|c|c|c|}
\hline \multirow{2}{*}{ Item } & \multirow{2}{*}{$\mathrm{MBW}^{1}$} & \multicolumn{4}{|c|}{ Water Intake (WI) } & \multirow{2}{*}{$\begin{array}{l}\text { Fecal } \\
\text { Water }\end{array}$} & \multirow{2}{*}{$\begin{array}{l}\text { Urine } \\
\text { Water }\end{array}$} & \multirow{2}{*}{$\begin{array}{c}\text { Total } \\
\text { output }\end{array}$} & \multirow{2}{*}{$\mathrm{IWL}^{3}$} \\
\hline & & Feed & Free & $\mathrm{MW}^{2}$ & Total & & & & \\
\hline R1-Control & $15.79^{b}$ & $71.46^{b}$ & $119.4^{b}$ & $26.64^{b}$ & $217.5^{b}$ & $\begin{array}{l}18.4^{\mathrm{b}} \\
(8.47)\end{array}$ & $\begin{array}{c}55.4 \\
(24.47)\end{array}$ & $\begin{array}{c}73.8^{b} \\
(33.93)\end{array}$ & $\begin{array}{c}144^{\mathrm{b}} \\
(66.07)\end{array}$ \\
\hline R2 & $16.65^{\mathrm{a}}$ & $71.08^{b}$ & $153.1^{\mathrm{a}}$ & $27.33^{\mathrm{ab}}$ & $251.5^{\mathrm{a}}$ & $\begin{array}{l}21.1^{\mathrm{a}} \\
(8.39)\end{array}$ & $\begin{array}{c}58.3 \\
(23.18)\end{array}$ & $\begin{array}{c}79.4^{\mathrm{a}} \\
(31.93)\end{array}$ & $\begin{array}{c}172^{\mathrm{a}} \\
(68.42)\end{array}$ \\
\hline R3 & $16.55^{\mathrm{a}}$ & $73.34^{\mathrm{a}}$ & $154.4^{\mathrm{a}}$ & $29.01^{\mathrm{a}}$ & $256.7^{\mathrm{a}}$ & $\begin{array}{c}22.6^{\mathrm{a}} \\
(8.80)\end{array}$ & $\begin{array}{c}57.7 \\
(22.48)\end{array}$ & $\begin{array}{c}80.3^{\mathrm{a}} \\
(31.28)\end{array}$ & $\begin{array}{c}176^{\mathrm{a}} \\
(67.72)\end{array}$ \\
\hline SEM & 0.26 & 2.05 & 6.15 & 0.09 & 3.46 & 0.81 & 0.62 & 0.77 & 5.47 \\
\hline$P$ value & 0.041 & 0.014 & 0.021 & 0.044 & 0.037 & 0.019 & 0.250 & 0.020 & 0.038 \\
\hline
\end{tabular}

${ }^{I} \mathrm{MBW}$ : metabolic body weight as $\mathrm{kg}^{0.82},{ }^{2} \mathrm{MW}$ : metabolic water, ${ }^{3} \mathrm{IWL}$ : Insensible water loss.

SEM: standard error of the means, $P$ value: probability value.

Values in brackets represent items as percentages of total water intake.

Means in the same line with different superscripted letters ( $a$ and $b$ ) are significantly different $(P<0.05)$. 
water execration were higher $(\mathrm{P}<0.01)$ for treatment groups $v s$. the control group. However, urine water was not affected by the experimental rations. This concurs with earlier reports by Helal et al. (2018) who recorded higher water intake $\left(220 \mathrm{ml} / \mathrm{kg} \mathrm{W}^{0.82}\right)$ for Barki sheep fed CFM plus either forage mixture including $25 \%$ sorghum vs. control group fed CFM plus alfalfa hay $\left(79.42 \mathrm{ml} / \mathrm{kg} \mathrm{W}^{0.82}\right)$. However, the revealed insensible water loss (IWL) for two groups was $150.58 \mathrm{vs}$. 131.80, respectively which were close to the present values for three groups $\left(144,172\right.$ and $176 \mathrm{~g} / \mathrm{kg}^{0.82}$ for R1, R2 and R3, respectively). The IWL presents $66.07,68.42$ and $67.72 \%$ of the total water intake of the corresponding three groups. These values were higher than that reported by Fahmy et al. (2010) who concluded that free water intake for sheep fed sorghum grass was $63.1 \mathrm{ml} / \mathrm{kg} \mathrm{BW}$ and the water balance was $41.1 \mathrm{ml} / \mathrm{kg} \mathrm{BW}$ which presented $54.7 \%$ of intake. A computing of IWL as a relative to water intake present estimations of 66.07 , 68.42 and 67.72 for T1, T2 and T3, groups, respectively, these values are within the range (52.5-78.4\%) reported by Kewan et al. (2016) for sheep fed dry forages.

\section{Rumen fermentation parameters:}

Data in Table (11) present the rumen fermentation parameters in Barki rams as a result of feeding the experimental rations. It is obvious that the maximum $(\mathrm{P}<0.05) \mathrm{pH}$ values were recorded at zero hour (before feeding) with all groups then significantly decreased with advanced time ( 3 and $6 \mathrm{~h}$ ) post-feeding in all treatments (Table 11). A similar trend was observed in the early study by Zaki et al. (2015). The rumen $\mathrm{pH}$ value of animal group fed control ration $(\mathrm{R} 1)$ was significantly $(\mathrm{P}<0.05)$ higher than other groups at all the sampling times. The $\mathrm{NH}_{3}-\mathrm{N}$ was significantly higher post-feeding than before feeding for all groups. Also, a comparable pattern was seen by Zaki et al. (2015). Animal group received R2 ration showed the highest $(\mathrm{P}<0.05)$ rumen $\mathrm{NH}_{3}-\mathrm{N}$ values at 3 and $6 \mathrm{~h}$ post-feeding as compared to the other groups; however R3 group showed the highest $(\mathrm{P}<0.05)$ value at zero hour post-feeding. In the present study, ruminal ammonia concentrations were in the range of those reported to be required for achieving the maximum ruminal microbial activity that was from 14.4 to $41.7 \mathrm{mg} / \mathrm{dl}$ (Borhami et al., 1998). Generally, ammonia level depends on CP content in the rations and degradability degree of $\mathrm{CP}$ in the rumen and in addition the amount of absorbed of ammonia through the blood stream in the rumen wall.

Table (11): Rumen fermentation parameters in Barki lambs fed experimental rations.

\begin{tabular}{|c|c|c|c|c|c|c|c|c|c|}
\hline \multirow{2}{*}{ Item } & \multicolumn{3}{|c|}{$\mathrm{pH}$} & \multicolumn{3}{|c|}{$\mathrm{NH}_{3}-\mathrm{N}, \mathrm{mg} / \mathrm{dl}$} & \multicolumn{3}{|c|}{ VFA, meq/dl } \\
\hline & 0 & $3 \mathrm{~h}$ & $6 \mathrm{~h}$ & 0 & $3 \mathrm{~h}$ & $6 \mathrm{~h}$ & 0 & $3 \mathrm{~h}$ & $6 \mathrm{~h}$ \\
\hline R1- Control & $6.50^{\mathrm{a}}$ & $6.37^{\mathrm{a}}$ & $6.13^{\mathrm{a}}$ & $15.94^{\mathrm{c}}$ & $19.17^{\mathrm{c}}$ & $18.69^{c}$ & 13.83 & 18.44 & $19.68^{\mathrm{ab}}$ \\
\hline $\mathrm{R} 2$ & $6.45^{b}$ & $6.31^{\mathrm{b}}$ & $5.95^{\mathrm{b}}$ & $17.00^{\mathrm{b}}$ & $25.34^{\mathrm{a}}$ & $32.30^{\mathrm{a}}$ & 14.93 & 19.62 & $22.14^{\mathrm{a}}$ \\
\hline R3 & $6.31^{\mathrm{c}}$ & $6.12^{\mathrm{c}}$ & $5.98^{\mathrm{b}}$ & $18.15^{\mathrm{a}}$ & $23.81^{\mathrm{b}}$ & $30.12^{\mathrm{b}}$ & 15.65 & 19.77 & $21.45^{\mathrm{b}}$ \\
\hline SEM & 0.10 & 0.01 & 0.01 & 0.12 & 0.33 & 0.25 & 0.44 & 0.63 & 0.51 \\
\hline$P$ value & 0.011 & 0.017 & 0.023 & 0.018 & 0.013 & 0.022 & 0.067 & 0.195 & 0.047 \\
\hline
\end{tabular}

SEM: standard error of the means, $P$ value: probability value.

Means in the same line with different superscripted letters $(a, b$ and $c)$ are significantly different $(P<0.05)$.

Volatile fatty acids are the major source of energy as they contribute by about $70 \%$ to the caloric requirements of ruminants as cited by Al Khalasi et al. (2010). In general view, the lowest TVFAs was recorded at $0 \mathrm{~h}$, and then increased up to $6 \mathrm{~h}$ post-feeding (Table 11). The differences of TVFAs at zero and $3 \mathrm{~h}$ among treatments were not significant and the corresponding values ranged from 13.83 to $15.65 \mathrm{meq} / \mathrm{dl}$ and from 18.44 to $19.77 \mathrm{meq} / \mathrm{dl}$, respectively. At $6 \mathrm{~h}$ post-feeding, group R2 showed the highest $(\mathrm{P}<0.05)$ value of TVFAs $(22.14 \mathrm{meq} / \mathrm{dl})$ as compared to the other groups $(19.68$ and 21.45 $\mathrm{meq} / \mathrm{dl}$ for R1 and R3, respectively). This indicates that the sorghum under the same condition of R2 and $\mathrm{R} 3$ is a good source for producing energy in sheep.

The present results of rumen $\mathrm{pH}$ and $\mathrm{NH}_{3}-\mathrm{N}$ are within the range recorded by Zaki et al. (2015) for ration contained Sesbania- Sorghum mixture (1:1) + CFM which were from 5.88 to 7.44 for $\mathrm{pH}$ and from 13.67 to $33.18 \mathrm{mg} / \mathrm{dl}$ for $\mathrm{NH}_{3}-\mathrm{N}$. Also, Avellaneda et al. (2009) reported a significant increase in $\mathrm{NH}_{3}-\mathrm{N}$ concentration in rumen liquor in lambs fed guinea grass supplemented with exotic enzymes. The present results of TVFAs are higher than that reported by Zaki et al. (2015) that was ranged from 4.17 to 7.00 meq/ dl, and these differences may be due to higher CFM intake in the present study and also higher soluble carbohydrates available for fermentation as a result of increasing the fiberolytic activity in the rumen. Also, the current results of rumen $\mathrm{pH}$ are similar to that recorded for silage of different sorghum varieties by Mahanta and Pachauri (2005) but higher in $\mathrm{NH}_{3}-\mathrm{N}$ and TVFAs. However, Al Khalasi et al. (2010) found no effect for sorghum irrigated with saline water at levels of 3, 6 and $9 \mathrm{dS} / \mathrm{m}$ on the rumen $\mathrm{pH}$ that was 6.2 on average. 
It is interesting to notice that higher P content in sorghum of R2 and R3 revealed significantly lower $\mathrm{pH}$ and at the same time, higher TVFAs as compared to the control group and these finding concurs with the recent study by Wang et al. (2021). Furthermore, lambs fed the control diet that was low in P and N consumed less food (Table 7), produced less rumen ammonia and microbial protein (as in Tables (5 and 11) so that grew at slower rates than those fed a diet rich in these nutrients (as in Table 7). This finding was consistent with earlier reports by Scott et al. (1997).

\section{Blood metabolites and element concentration:}

Results in Table (12) present blood biochemical and electrolyte components in lambs as influenced by the experimental rations. Total protein was significantly $(\mathrm{P}<0.001)$ higher $(6.35 \mathrm{~g} / \mathrm{dl})$ for lambs fed $\mathrm{R} 2$ than that fed R1 or R3 (4.70 and $5.33 \mathrm{~g} / \mathrm{dl}$, respectively) which were practically equivalent. However, albumin concentration was significantly $(\mathrm{P}<0.05)$ higher for $\mathrm{R} 3(4.33 \mathrm{~g} / \mathrm{dl})$ than that in both $\mathrm{R} 1$ and $\mathrm{R} 2$ being 2.40 and $3.50 \mathrm{~g} / \mathrm{dl}$, respectively. These results concur with those reported by Shaker et al. (2008) and also Shaker (2014) who reported that animals fed salt tolerant plants combination of Atriplex nummularia, Sorghum bicolor and Pearl millet had insignificantly lower mean values of total protein $(4.80 \mathrm{~g} \%)$ and albumin $(7.32 \mathrm{~g} \%)$ in comparison with control ones. The reduction of TP and albumin concentration in treated animals might be ascribed to the high content of tannins and oxalates in such salttolerant plants where tannins were reported to decrease the digestibility of crude protein (Mahmoud, 2001). Furthermore, higher salt intake might be another motivation to present such decrement in TP and Alb, levels (Badawy, 1999). According to another perspective, the slight decline in total proteins fraction could be ascribed to the lower crude protein recorded in ration R1. Shahen et al. (2004) reported a positive correlation between dietary protein and plasma protein concentration. On the contrary, Mahanta and Pachauri (2005) presumed that different varieties of sorghum silage did not have any impact on the concentration of blood metabolites (plasma protein and urea-N) in sheep. In the present study, blood urea$\mathrm{N}$ and creatinine values followed the same pattern where comparable values were observed for R2 and R3 groups and at the same time they are significantly higher than those in R1. Plasma urea-N reflects the dietary CP intake, the ratio of dietary CP to ruminally fermentable OM, and also serves as an indicator of ruminal protein supply. Blood urea-n and creatinine are the two major nitrogenous compounds eventually excreted by the kidney and accordingly, any change of their concentration would reflect impaired glomerular filtration and/ or potentially inadequacy of renal tubules (Kaneko et al., 2008). Moreover, urea is the significant nitrogenous metabolic product of protein catabolism representing over $75 \%$ of the nonprotein-N excreted. Otherwise, production is dependent on several non-real variables like a diet regimen and hepatic synthesis.

A decrease in urea concentration of R1 group could be attributable to the presence of tannins, which diminish the degradation of the ruminal proteins (Brooke et al., 1997). In accordance, Cook et al. (2008) detailed that plasma urea nitrogen was brought down in sheep and goats fed high tannins legumes. Pearce et al. (2008) reported that treatment significantly affected plasma urea concentrations $(\mathrm{P}<0.001)$ where sheep fed the control diet had significantly higher plasma urea concentrations than their mates fed the saltbush diet. However, Badawy et al. (2002) found that animals fed fresh saltbush had high urea values comparing with the control group. Feeding a mixture of Atriplex nummularia, Sorghum bicolor and Pearl millet forages increased the serum creatinine concentration comparing to the control group in a reverse trend with that of urea results. Consistently, Badawy et al. (2002) and Shaker et al. (2008) found that animals fed fresh Atriplex had higher values of creatinine than their counterparts fed on control ration. This increment in creatinine levels could be a result of anti-nutritional factors (tannin and oxalates) and/ or high salt in such salt-tolerant plants. On the other hand, the high content of salt in such salt-tolerant forage mixture might be the clue to understanding the increment observed in creatinine level.

Table (12): Blood biochemical and electrolyte components in lambs fed the experimental diets.

\begin{tabular}{lccccccccc}
\hline Item & $\begin{array}{c}\mathrm{TP} \\
\mathrm{g} / \mathrm{dL}\end{array}$ & $\begin{array}{c}\mathrm{Alb} \\
\mathrm{g} / \mathrm{dL}\end{array}$ & $\begin{array}{c}\mathrm{Urea} \\
\mathrm{mg} / \mathrm{dl}\end{array}$ & $\begin{array}{c}\mathrm{Cr} . \\
\mathrm{Mg} / \mathrm{dl}\end{array}$ & $\begin{array}{c}\mathrm{NH}_{3} \\
\mu \mathrm{mol} / \mathrm{l}\end{array}$ & $\begin{array}{c}\mathrm{Na} \\
\mathrm{mEq} / \mathrm{l}\end{array}$ & $\begin{array}{c}\mathrm{K} \\
\mathrm{mEq} / \mathrm{l}\end{array}$ & $\begin{array}{c}\mathrm{Ca} \\
\mathrm{mg} / \mathrm{dl}\end{array}$ & $\begin{array}{c}\mathrm{P} \\
\mathrm{mg} / \mathrm{dl}\end{array}$ \\
\hline $\mathrm{R} 1-C o n t r o l$ & $4.70^{\mathrm{b}}$ & $2.40^{\mathrm{c}}$ & $18.00^{\mathrm{b}}$ & $0.36^{\mathrm{b}}$ & 289.8 & 142 & 4.35 & 9.98 & 9.01 \\
$\mathrm{R} 2$ & $6.35^{\mathrm{a}}$ & $4.33^{\mathrm{a}}$ & $26.25^{\mathrm{a}}$ & $0.61^{\mathrm{a}}$ & 374.5 & 140 & 6.05 & 8.88 & 9.51 \\
$\mathrm{R} 3$ & $5.33^{\mathrm{b}}$ & $3.50^{\mathrm{b}}$ & $27.75^{\mathrm{a}}$ & $0.58^{\mathrm{a}}$ & 318.3 & 138 & 6.18 & 8.35 & 9.66 \\
\hline $\mathrm{SEM}$ & 0.18 & 0.22 & 0.91 & 0.054 & 44.63 & 2.26 & 0.87 & 0.60 & 1.41 \\
$\mathrm{P}$ value & 0.001 & 0.028 & 0.001 & 0.017 & 0.428 & 0.568 & 0.299 & 0.202 & 0.946 \\
\hline
\end{tabular}

TP: total protein, Alb: albumin, Cr: creatinine, NH3: ammonia, Na: sodium, K: potassium, Ca: calcium, P: phosphorus. SEM: standard error of the means, $P$ value: probability value.

Means in the same line with different superscripted letters $(a, b$ and $c)$ are significantly different $(P<0.05)$. 
Minerals play a vital role in the regulation of body fluids, acid base balance and metabolic processes. Data in Table (12) show that there are no significant $(\mathrm{P}>0.05)$ differences between the experimental groups regarding the electrolytes under investigation $(\mathrm{Na}, \mathrm{K}, \mathrm{Ca}$ and $\mathrm{P})$. A different pattern of response has previously been seen in growing lambs fed low $\mathrm{P}$ diets which resulted in a fall in plasma $\mathrm{P}$ and a rise in plasma Ca (Scott et al., 1997). Shaker et al. (2008) reported that serum $\mathrm{Na}^{+}$level significantly increased in animals fed atriplex. Concerning of $\mathrm{K}$ concentration, animals fed salt tolerant forages mixture had higher mean plasma $\mathrm{K}$ concentration value than the control group. In agreement, Badawy et al. (2002) reported that animals fed atriplex had higher $\mathrm{K}^{+}$concentration. This pattern of potassium was in complete harmony with that of sodium.

\section{CONCLUSION}

It could be concluded that, both of the sorghum treatments; $\mathrm{N}_{120} \mathrm{P}_{30}$ and $\mathrm{N}_{100} \mathrm{P}_{40} \mathrm{~kg} / \mathrm{fed}$; are in the same nutritive values and similar growth rate for Barki lambs. However, because of higher $\mathrm{P}$ drain away to the land below in case of $\mathrm{N}_{100} \mathrm{P}_{40}$ ration so it is recommended for $\mathrm{N}_{120} \mathrm{P}_{30}$ to be a better fertilizer rate for the fodder consumed by the Barki lambs and for its potential to reduce the environmental pollution with the high level of $\mathrm{P}$ compared to the other treatment.

\section{ACKNOWLEDGEMENT}

The authors are thankful to Dr. Ibrahim Abou-Amer, Soil Fertility and Microbiology Department, Water Resources and Desert Soils Division, Desert Research Center (DRC), for assistance in the agronomy experiment.

\section{REFERENCES}

Abdi, H., and L.J. Williams (2010). Tukey's honestly significant difference (HSD) test. Encyclopedia of Research Design, 3(1), 1-5.

Aganga, A.A. and M.N. Autlwetse (2000). Utilization of sorghum forage, millet forage, veldt grass and Buffel grass by Tswana sheep and goats when fed Lablab purpureus L. as protein supplement. AsianAus, J. Anim. Sci., 13 (8): 1127-1132.

Al Khalasi, S.S., O. Mahgoub, I.T. Kadim, W. Al-Marzouqi and S. Al-Rawahi (2010). Health and performance of Omani sheep fed salt-tolerant sorghum (Sorghum bicolor) forage or Rhodes grass (Chloris gayana). Small Ruminant Research, 91: 93-102.

Allam, S.M., H.M. El-Shaer, K.M. Youssef, M.A. Ali and S. Abo Bakr (2009). Impact of feeding biologically treated wheat straw on the production performance of goats in North Sinai. World J. Agric. Sci., 5(5): 535-543.

Almodares, A., M. Jafarinia and M.R. Hadi (2009). The effects of nitrogen fertilizer on chemical compositions in corn and sweet sorghum. American-Eurasian J. Agric. Environ. Sci., 6 (4): 441-446.

AOAC (1997). Association of Official Analytical Chemists, Official Methods of Analysis, $16^{\text {th }}$ ed. AOAC, Arlington, VA, USA.

AOAC (2000). Association of Official Analytical Chemists, Official Methods of Analysis, 17th Ed. Arlington, VA, USA.

Astuti, D., B. Suhartanto, N. Umami and A. Irawan (2019). Productivity, Nutrient Composition, and Hydrocyanic Acid Concentration of Super-2 Forage Sorghum at Different NPK Levels and Planting Spaces. Tropical Animal Science Journal, 42(3):189-195.

Avellaneda J.H., J.M. Pinos-Rodriguez, S.S. Gonzalez, R. Barcenac, M. Hernandezc, A. Cobos, O. Hernandez and D. Montanez (2009). Effects of exogenous fibrolytic enzymes on ruminal fermentation and digestion of guinea grass hay. Animal Feed Science and Technology, 149: 70-77.

Badawy, M. S. M. (1999). Digestive function and heat regulation in Saidi sheep. M. Sc. Thesis, Assiut University, Egypt. 


\section{Kewan et al.}

Badawy, M. T., H.A. Gawish and A.A. Younis (2002). Some physiological responses of growing Barki lambs and Baladi kids fed natural desert shrubs. International Symposium on Optimum Resources Utilization in Salt - Affect Ecosystems in Arid and Semi- arid Regions. Cairo, 8- 11, April, 496- 503.

Borhami, E.B., A.Z. Salem, W.G. Fahmy and M.H.M. Yacout (1998). Effect of berseem and ammoniated corn stalks residues supplementation on performance of lactating goats. Proceedings of an International Conference on Odder, Water Quality Nutrient Management and Socioeconomic Issues. Lowa State Univ. of Sci \& Tech. July 19-22. Vol. 11:531.

Brooke, I. M., C.W. Holmes and G.F. Wilson (1997). Effect of Mimosa bark extracts containing condensed tannins on rumen metabolism in sheep and milk production by grazing cows. ProceedingsNew Zealand Society of Anim. Prod., 57: 126.

Chakravarthi, M.K., Y. R. Reddy, K. S. Rao, A. Ravi, B. Punyakumari and B. Ekambaram (2017). A study on nutritive value and chemical composition of Sorghum fodder. International Journal of Science, Environment and Technology, 6 (1): 104 - 109.

Conn, E.E. (1993). b-Glycosidases in plants. Substrate specificity. In: A. Esen (Ed.) b-Glucosidases: Biochemistry and Molecular Biology, ACS Symposium Series 533. American Chemical Society, Washington, DC, pp. 15-26.

Cook, R. W., C.B. Scott and F.S. Hartmann (2008). Short-term Mesquite pod consumption by goats does not induce toxicity. Rangeland Ecology \& Management, 61 (5): 566- 570.

Czerkawski J.W. (1985). An introduction to rumen studies. Pergamon Press, Oxford, UK.

Das, S. K., K. L. Sharma, B. R. Singh, C. P. Rao, K. Srinivas, and M. N. Reddy (1996). Availability of desorbed phosphorus and internal phosphorus requirement by sorghum in an Alfisol. J. India Soc. Soil Sci., 44(3) 427-433.

Demeyer, D., M. De Meulemeester, K. De Graeve and B.W. Gupta (1988). Effect of fungal treatment on nutritive value of straw. Med. Fac. Landbouww. Rijksuniv. Gent, 53: 1811-1819.

Fahmy, A.A, K.M Yousef and H.M. El Shaer (2010). Intake and nutritive value of some salt tolerant fodder grasses for sheep under saline conditions of South Sinai, Egypt. J. Small Rum. Res., 91:110115 .

Getachew G., Makkar H.P.S. and K. Becker (2002). Tropical browses: content of phenolic compounds, in vitro gas production and stoichiometric relationship between short chain fatty acids and in vitro gas production. J. Agr. Sci., 139: 341-352.

Getachew, G, D. H. Putnam, C. M. De Ben and E. J. De Peters (2016). Potential of Sorghum as an alternative to corn forage. American Journal of Plant Sciences, 7: 1106-1121.

Gorz, H.J., W.L. Haag, J.E. Specht and F.A. Haskins (1977). Assay of p-Hydroxybenzaldehyde as a measure of Hydrocyanic Acid potential in Sorghums. Crop Science (July-August) 17.

Helal H. G., E.Y. Eid, M.S. Nassar, H.S. Badawy and H.M. El Shaer (2018). Comparative nutritional studies of ewes and does fed salt tolerant plants under desert condition. Nature and Sci., 16 (6):62-72.

Hernandez, R., S.S. Gonzalez, J.M. Pinos-Rodrigues, M.A. Ortega, A. Hernandez, G. Bueno and M. Cobos (2009). Effect of yeast culture on nitrogen balance and digestion in lambs fed early and mature orchard grass. J. Appl. Anim. Res., 32: 53- 56.

Heseen, E. M., S. Mervat Hassan, M. M. Azza Badr, Sh. Fatma Ismail and A. Fatma Abd-Elsalam (2017). Effect of using different fertilizers sources on forage sorghum yield, digestibility and energy parameters by in vitro gas test production. Annals Agric. Sci., Moshtohor, 55(4): 805 -816.

Hussein, M.M. and M.M. Sabbour (2014). Effect of irrigation intervals and nitrogen fertilizer on yield and water use efficiency of sorghum fodder. Int. J. Sci. and Res., 3 (11): 404-410.

Kaneko, J.J., J.W. Harvey and M.L. Bruss (2008). Clinical Biochemistry of domestic Animals. $6^{\text {th }}$ ed. San Diego: Academic Press. 904p.

Karsil, M.A. and J.R. Russell (2001). Effect of some dietary factors on ruminal microbial protein synthesis. J. Veterinary and Animal Science, 25: 681-685.

Karthika, N and R. Kalpana (2017). HCN content and forage yield of multi-cut forage sorghum under different organic manures and nitrogen levels. Chem. Sci. Rev. Lett., 6(23): 1659-1663. 
Kearl, L.C. (1982). Nutrients requirements in developing countries. International Feedstuffs Institute Utah Agric. Exp. Stat.; Utah State University, Logan; USA.

Kewan, K. Z. A., F.A. Salem, Ahllam R. Abdou, H.M. El-Sayed, S.S.S. Eisa and E.A. Zaki (2016). Upgrading nutritional value of moringa stalks by using Trichoderma reesei, Cellulomonas cellulasea and Saccharomyces cerevisiae in solid state fermentation system. J. Environ. Sci., 33(2):213-240.

Kewan, K.Z., A.A. Elkhouly, A.M. Negm and A. Javadi (2019). Feedstock values of some common fodder halophytes in the Egyptian desert. $22^{\text {nd }}$ International Water Technology Conference, IWTC22 Ismailia, 12-13 September 2019.

Kewan, K.Z., Abeer M. EL-Essawy, Safinaz, M. Shawket and H.M. El-Shaer (2011). Effect of energy sources supplement for camels fed berseem hay on: 2. Metabolism of water and some mineral elements. Egypt. J. Nutr. Feeds, 14(1):63-75.

Khan, S.H., A.G. Khan, M. Sarwar and A. Azim (2007). Effect of maturity on production efficiency, nutritive value and in situ nutrients digestibility of three cereal fodders. International Journal of Agricultural Research, 2: 900-909.

Khanum, S.A., H.N. Hussain, M. Hussain and M. Ishaq (2010). Digestibility studies in sheep fed sorghum, sesbania and various grasses grown on medium saline lands. Small Ruminant Research, 91: 63-68.

Khattari, S. and A. Tell (1988). Response of wheat varieties to P fertilizers under a wide range of rainfall. In: "Challenges in Dryland Agriculture", P.W. Unger, T.V. Sneed, W.R. Jordan and R. Jensen (Ed.), pp. 429-31, Proc. Int. Conf. Dryland Farming, Amarillo, Texas, U.S.A.

Korkmaz, K., H. Ibrikci, E. Karnez, G. Buyuk, J. Ryan, A. Ulger and H. Oguz (2009). Phosphorus use efficiency of wheat genotypes grown in calcareous soils. Journal of Plant Nutrition, 32(12), 20942106.

Louvandini, H. and D.M.S.S. Vitti (2007). Phosphorus kinetics using mathematical models for adult sheep. Pesquisa Agropecuaria Brasileira, 42: 1467-1472.

Mahanta, S.K. and V. C. Pachauri (2005). Nutritional Evaluation of Two Promising Varieties of Forage Sorghum in Sheep Fed as Silage. Asian-Aust. J. Anim. Sci., Vol 18, No. 12 : 1715-1720.

Mahmoud, H. A. (2001). Physiological and nutritional studies on sheep feeding certain halophytic plants in Sinai. M. Sc. Thesis, Fac. of Sci., Cairo University, Giza, Egypt.

Majak, W., R.E. McDiarmid, J.W., Hall and K.J. Cheng (1990). Factors that determine rates of Cyanogenesis in Bovine ruminal fluid in vitro. Journal of Animal Science, 68: 1648-1655.

Makkar, H.P.S., P. Siddhuraju and K. Becker (2007). Plant secondary metabolites. Humana Press, Totowa, New Jersey. pp130.

Masters, D.G., S.E. Benes and H.C. Norman (2007). Biosaline agriculture for forage and livestock production. Rev. Agric. Ecosyst. Environ, 119: 234-248.

Meena, A.M, P. Singh and P. Kanwar (2012). Effect of nitrogen levels on yield and quality of Sorghum bicolor (L.) Moench, sorghum genotypes. Forage Res., 37(4): 238-240.

Menke, K. H. and H. Steingass (1988). Estimation of the energetic feed value obtained from chemical analysis and in vitro gas production using rumen fluid. Anim. Res. Dev., 28:7-12.

Mostafa, M.R.M, S.B. Mehany, Safaa N. Abd El-Azim and Soheur J. Latif (2010). Effect of using three varieties of Sorghum bicolor stover silages on performance of growing and fattening lambs. Egyptian J. Nutr. Feeds, 13(2):271-283.

NRC (1985). National Research Council. Nutrient Requirements of Sheep. $6^{\text {th }}$ ed. National Academy Press, Washington, DC.

Obour, A., J.D. Holman and D.B. Mengel (2018). Nitrogen application effects on forage sorghum biomass production and nitrates. Kansas Agricultural Experiment Station Research Reports, 4(5): 4.

Pearce, K. L., D.W. Pethick and D.G. Masters (2008). The effect of ingesting a saltbush and barley ration on the carcass and eating quality of sheep meat. Animal, 2 (3): 479-490. 


\section{Kewan et al.}

Pholsen S. and A. Suksri (2004). Effect of organic amendment and chemical fertilizer on growth, yield and fodder quality of a forage sorghum (Sorghum bicolor (L.) moench). Pakistan Journal of Biological Sciences, 7 (4): 651-657.

Piri, A., V. Palangi and P. Eivazi (2012). The determination of nutritive value of alhagi by in situ and gas production techniques. European Journal of Experimental Biology, 2 (3):846-849.

Preston, T.R. (1995). Biological and Chemical Analytical Methods. Tropical animal feeding: a manual for research workers. Rome: FAO (1995): 191-264.

Rashid, M. and M. Iqbal (2011). Response of sorghum (Sorghum bicolor L.) fodder to phosphorus fertilizer on torripsamment soil. J. Animal Plant Sci., 21(2): 220-225.

Sanchez, A.C., P.K. Subudhi, D.T. Rosenow and H.T. Jguyen (2002). Mapping QTLs associated with drought resistance in sorghum (Sorghum bicolor L. Moench). Plant Mol. Biol., 48: 713-726.

Sarfraz, M., A. Nisar, U. Farooq, A. Azhar and H. Khalid (2012). Evaluation of Sorghum varieties/lines for hydrocynic acid and crude protein contents. J. Agric. Res., 50(1): 39-47.

SAS (2002). Institute. SAS/STAT User's Guide: Version 8.2. SAS Institute Inc., Cary, NC.

Scott, D., N. Loveridge, L. Nicodemo, W. Buchan, J. Milne, A. Duncan, P. Nicol and S. P. Robins (1997). Effect of diets varying in nitrogen or phosphorus content on indicators of bone growth in lambs. Experimental Physiology, 82: 193-202.

Shahen, G. F., A.A. Zaki and H.M. Yousef (2004). Effect of feeding level on growth nutrient digestibility and feed efficiency for buffalo calves. Egyptian Journal of Nutrition and Feeds, 7: 11.

Shaker, Y.M. (2014). Live Body weight changes and physiological performance of Barki sheep fed salt tolerant fodder crops under the arid conditions of Southern Sinai, Egypt. J. Am. Sci., 10(2s):78-88.

Shaker, Y. M.; S.S. Abou El-Ezz and A.L. Hashem (2008). Physiological performance of Barki male lambs fed halophytes under semi-arid conditions. J. Agric. Sci. Mansoura Univ., 33 (9): 6393- 6408.

Sher, A., B. Lorenzo, A. Muhammad, M. Abdul and K. Shuaib (2011) Late harvest associated with P and $\mathrm{S}$ fertilization enhances yield and quality of forage sorghum (Sorghum bicolor L. Moench), grown as a rainfed crop in Pakistan. African Journal of Agricultural Research, 6(29): 6232-6239.

Sheridan, K.P., J.F. Holland, J.A. Thompson and B.A. Hamilton (2003). Growth rates of lambs and adult sheep grazing forage sorghums and Lucerne. Aust. J. Exp. Agric. Anim. Husb., 12: 144-145.

Singh, H., S. Pushpendra and H.K. Sumerhya (2008). Effect of fertility leves on fodder yield and HCN content of fodder sorghum (Sorghum bicolor L. Moench) genotypes. Inter. J. Trop. Agri., 26: 417-420.

Singh, S., B., B.V. Bhat, G.P. Shukla, D. Gaharana and U.Y. Anele (2017). Nutritional evaluation of different varieties of sorghum stovers in sheep. Animal Feed Science and Technology, 227: 42-51.

Talpada, M.M., G.B. Vekariya, G.S. Sutaria and V.D. Vora (2016). Response of forage sorghum (cv. CSV 21F) to seed rate and fertilizer level. Indian J. Dryland Agric. Res. \& Dev., 2016 31(1): 77-82

Thiex, Nancy J. (2002). Prussic Acid Poisoning. Fact sheets, SDSU Extention, South Dakota State University Open PRAIRIE: Open Public Research Access Institutional Repository and Information Exchange. 3-1-2002.

Thota, P., S. A. Chandra, M. Mahender and D.B.V. Ramana (2017). Effect of probiotic supplementation on nutrient digestibilities, growth performance and enteric methane emissions in Deccani ram lambs. Journal of Animal Research, Vol.7 (6) :1009-1017.

VDLUFA (2007). Verband deutscher landwirtschaftlicher Untersu-chungs- und Forschungsanstalten. (2007). Handbuch der Landwirtschaftlichen Versuchs- und Untersuchungs-methodik (VDLUFAMethodenbuch), Bd. III: Die chemische Untersuchung von Futtermitteln. VDLUFA-Verlag, Darmstadt, Germany.

Udayakumar, S. and R. Santhi (2017). Impact of artificial soil fertility gradient strategy on soil fertility, nutrient uptake and fodder yield of Sorghum. Int. J. Curr. Microbiol. App.Sci., 6(3): 938-944.

Wang, T., J. Jiao, H. Wang, A. A. Degen, N. G. Shanshan Li, Y. Bai and Z. Shang (2021). The effects of supplementing sweet sorghum with grapeseeds on dry matter intake, average daily gain, feed digestibility and rumen parameters and microbiota in lambs. Animal Feed Science and Technology, 272: 114750 . 
Ward, J. D., D. D. Redfearn, M. E. Mc Cormick and G. J. Cuomo (2001). Chemical composition, ensiling characteristics and apparent digestibility of summer annual forages in a subtropical double cropping system with annual rye grass. J. Dairy Sci., 84:177-182.

Wheeler, J.L., D.A. Hedges, K.A. Archer and B.A. Hamilton (1980). Effect of nitrogen, sulphur and phosphorus fertilizer on the production, mineral content and cyanide potential of forage sorghum. Aust. J. Exp. Agric. Anim. Husbandry, 20: 330-338.

Zaki, M. A., A. A. Osman, Fathia A. Ibrahim and E. S. Soliman (2015). Effect of using Sesbania sesban and its mixtures with some Summer fresh grasses on lambs productive performance in new reclaimed soil. Journal of Animal, Poultry and Fish Production Suez Canal University, (3): 7-16.

\title{
تأثير التسميد غير العضوي على جودة علف السورجم ونمو العملان البرقي
}

\author{
خالد زين العابدين كيوان1، أبراهيم محم خطاب، عادل محم عبد الواحد1، اسامه أبو العز نايل33

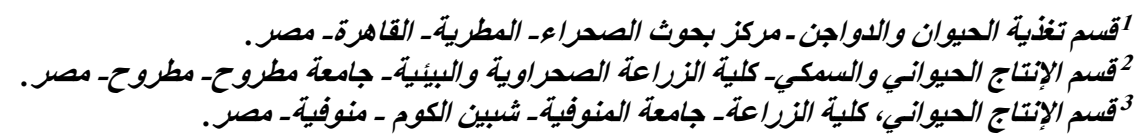

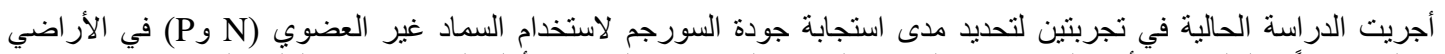

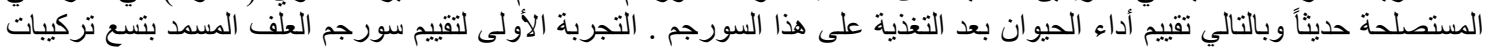

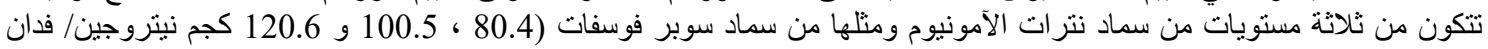

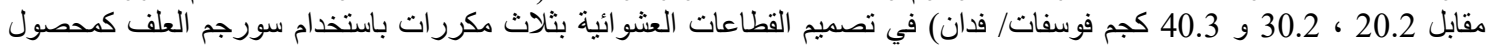

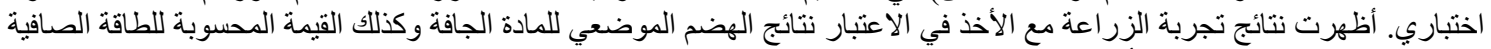

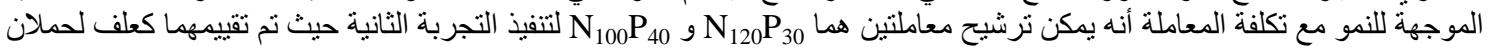

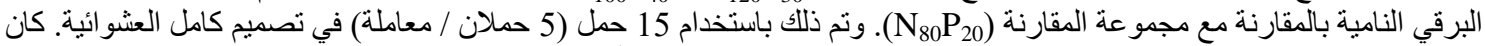

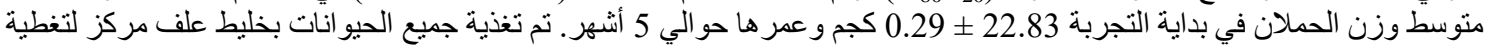

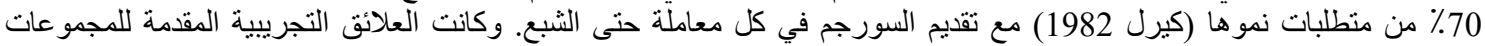

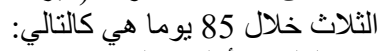

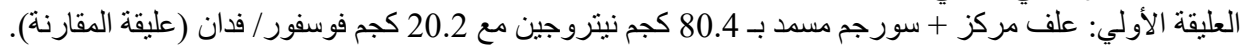

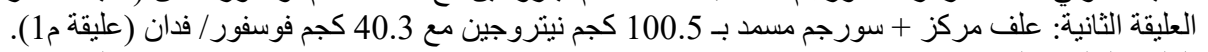
العليقة الثالثة: علف مركز + سورجم مسمد بـ 120.6 كجم نيتروجين مع دئر 30.2 كجم فوسفور / فدان (عليقة م2). ويمكن إيجاز النتائج في الآتي: علئ ملئ

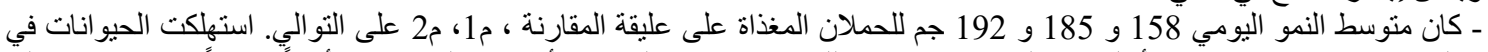

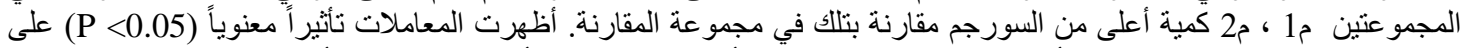

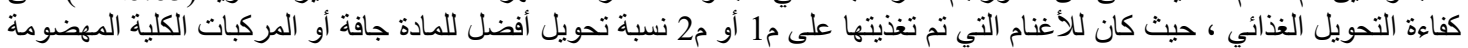

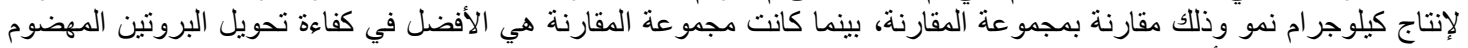

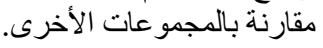

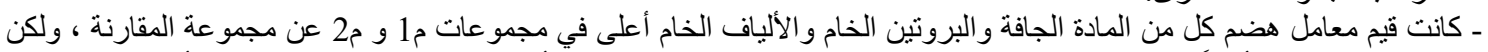

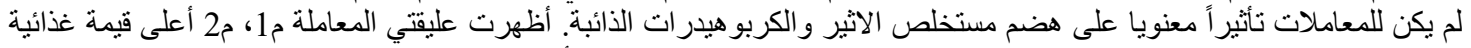

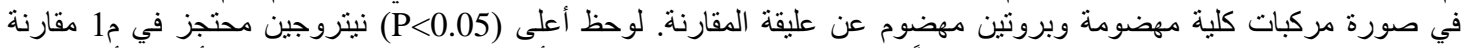

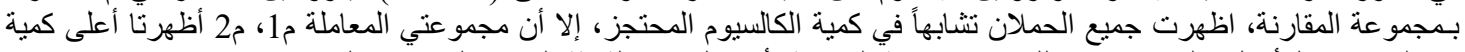

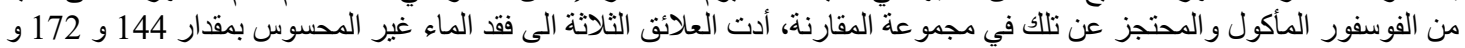

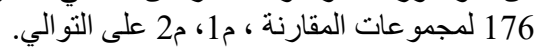

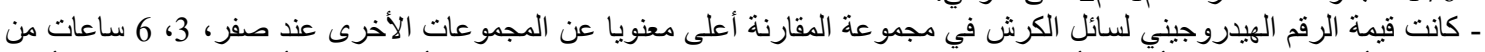

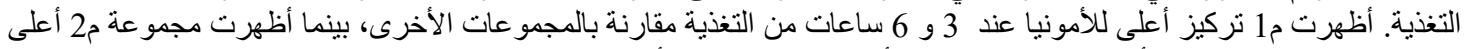

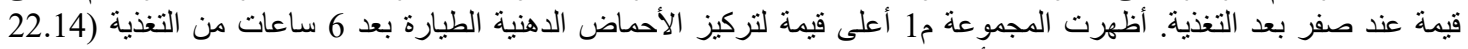

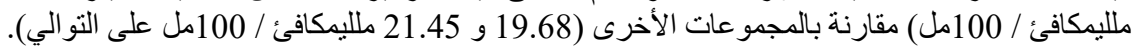

يمكن استتناج أن معاملتي التسميد

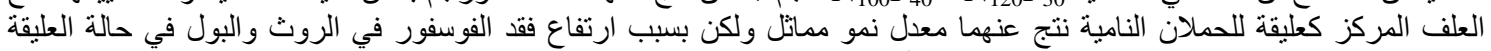

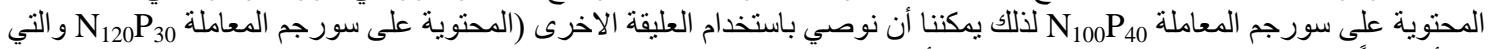

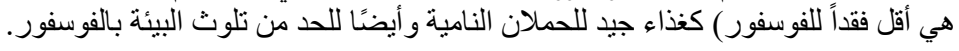

